\title{
Boulder accumulations related to extreme wave events on the eastern coast of Malta
}

\author{
Sara Biolchi ${ }^{1}$, Stefano Furlani ${ }^{1}$, Fabrizio Antonioli ${ }^{2}$, Niccoló Baldassini ${ }^{3}$, Joanna Causon Deguara ${ }^{4}$, Stefano Devoto ${ }^{1}$, \\ Agata Di Stefano $^{3}$, Julian Evans ${ }^{5}$, Timothy Gambin ${ }^{6}$, Ritienne Gauci ${ }^{4}$, Giuseppe Mastronuzzi ${ }^{7}$, Carmelo Monaco ${ }^{3}$, \\ and Giovanni Scicchitano ${ }^{3,8}$ \\ ${ }^{1}$ Dipartimento di Matematica e Geoscienze, Università di Trieste, Via Weiss 2, 34127 Trieste, Italy \\ ${ }^{2}$ ENEA, UTMEA, Casaccia, Rome, Italy \\ ${ }^{3}$ Dipartimento di Scienze Biologiche, Geologiche e Ambientali, Sezione Scienze della Terra, Università di Catania, \\ Corso Italia 57, 95129 Catania, Italy \\ ${ }^{4}$ Department of Geography, University of Malta, 2080 Msida, Malta \\ ${ }^{5}$ Department of Biology, University of Malta, 2080 Msida, Malta \\ ${ }^{6}$ Department of Classics and Archaeology, Archaeology Centre, University of Malta, 2080 Msida, Malta \\ ${ }^{7}$ Dipartimento di Scienze della Terra e Geoambientali, Via Orabona 4, Università di Bari, 70125 Bari, Italy \\ ${ }^{8}$ Studio Geologi Associati T. S. T., Via Galliano 157, Misterbianco (Ct), Italy
}

Correspondence to: Stefano Devoto (sdevoto@units.it)

Received: 2 September 2015 - Published in Nat. Hazards Earth Syst. Sci. Discuss.: 6 October 2015

Revised: 2 March 2016 - Accepted: 3 March 2016 - Published: 16 March 2016

\begin{abstract}
The accumulation of large boulders related to waves generated by either tsunamis or extreme storm events have been observed in different areas of the Mediterranean Sea. Along the eastern low-lying rocky coasts of Malta, five sites with large boulder deposits have been investigated, measured and mapped. These boulders have been detached and moved from the nearshore and the lowest parts of the coast by sea wave action. In the Sicily-Malta channel, heavy storms are common and originate from the NE and NW winds. Conversely, few tsunamis have been recorded in historical documents to have reached the Maltese archipelago.

We present a multi-disciplinary study, which aims to define the characteristics of these boulder accumulations, in order to assess the coastal geo-hazard implications triggered by the sheer ability of extreme waves to detach and move large rocky blocks inland.

The wave heights required to transport 77 coastal boulders were calculated using various hydrodynamic equations. Particular attention was given to the quantification of the input parameters required in the workings of these equations, such as size, density and distance from the coast. In addition, accelerator mass spectrometry (AMS) ${ }^{14} \mathrm{C}$ ages were determined from selected samples of marine organisms encrusted
\end{abstract}

on some of the coastal boulders. The combination of the results obtained both by the hydrodynamic equations, which provided values comparable with those observed and measured during the storms, and radiocarbon dating suggests that the majority of the boulders have been detached and moved by intense storm waves. These boulders testify to the existence of a real hazard for the coasts of Malta, i.e. that of very high storm waves, which, during exceptional storms, are able to detach large blocks of volumes exceeding $10 \mathrm{~m}^{3}$ from the coastal edge and the nearshore bottom, and also to transport them inland. Nevertheless, the occurrence of one or more tsunami events cannot be ruled out, since radiocarbon dating of some marine organisms did reveal ages which may be related to historically known tsunamis in the Mediterranean region, such as the ones in AD 963, 1329, 1693 and 1743.

\section{Introduction}

The central part of the Mediterranean Sea often experiences strong winds and high waves related to marine storms, which are common during both the winter and autumn seasons. In recent years they have been linked to an increase in the oc- 
currence of violent "tropical-like cyclone" events (Emanuel, 2005; Fita et al., 2007; Lionello et al., 2006). Such a type of storm waves may represent a severe geo-hazard for inshore facilities and related land use development, as evidenced by the recent impact of severe storms on the coasts of Apulia (southern Italy) which caused extensive flooding both on Ionian and Adriatic sides. In historical and recent times, tsunamis of impressive heights have been recorded to have hit some parts of the Mediterranean coasts. The 1908 earthquake-generated tsunami that struck the coasts of Calabria and Sicily in southern Italy developed waves up to $13 \mathrm{~m}$ above sea level, contributing to heavy destruction and 1500 casualties (Bertolaso et al., 2008). More recently, in 2006, the collapse of Sciara del Fuoco along the flanks of the Stromboli volcano island generated waves that destroyed harbour structures and other facilities on the island and along the Tyrrhenian coasts of Calabria and Sicily (Mastronuzzi et al., 2013a).

In the Maltese archipelago the recorded tsunamis (Tinti et al., 2004) are the ones of AD 1169, 1693 (described locally also by Agius de Soldanis in 1746) and 1908. The latter is well known to have affected the eastern coast of Malta (Pino et al., 2008) and the southern coast of Gozo with a wave height ranging between 0.72 and $1.50 \mathrm{~m}$ (Guidoboni and Mariotti (2008) and references therein). These events have been triggered by earthquakes which occurred in eastern Sicily. Moreover, according to the model provided by Tinti el al. (2005), a potential tsunami impacting on the Maltese coasts may be generated either by an earthquake of $M_{\mathrm{w}}=7.4$ along an offshore fault located parallel to the Malta Escarpment (the former considered as one of the possible sources for the AD 1693 earthquake) with a wave height of $0.15-1 \mathrm{~m}$, or by an earthquake from the western Hellenic Arc $\left(M_{\mathrm{w}}=8.3\right)$ with marginally higher wave heights $(1-1.5 \mathrm{~m})$.

One of the most impressive pieces of evidence of extreme wave impact on the Mediterranean coasts is represented by the occurrence of mega-boulders, sparse or in fields or berms whose accumulations have been attributed both to tsunamis and storm events (Mastronuzzi and Sansò, 2000, 2004; Mastronuzzi et al., 2007; Scicchitano et al., 2007, 2012; Barbano et al., 2010; Vacchi et al., 2012; Raji et al., 2015). Notwithstanding the impressive growth in the last 50 years of studies aimed to develop an appropriate methodology, which may (in the absence of field witnesses) link these boulder deposits to a well-defined process (Williams and Hall, 2004; Hall et al., 2006; Mastronuzzi et al., 2006; Scheffers and Scheffers, 2006; Pignatelli et al., 2009; Goto et al., 2010), no undisputed consensus has yet been reached on how to differentiate between the boulders accumulated by a sea storm from those deposited by a tsunami. Some studies point to the presence of boulders and their size, to evaluate the characteristics of the impacting waves (i.e. Mastronuzzi and Pignatelli (2012); Mastronuzzi et al. (2013b) and references therein). An important degree of uncertainty lies in this methodology due to the definition of the origin of the wave responsible for the de- position of the boulders. The hydrodynamics of boulder emplacement and transport to the shore platform have been dealt with, among others, by Nott $(1997,2003)$ and Noormets et al. (2004). Nott attributes the force required to transport boulders to wave height and proposes a straightforward method to determine if storm or tsunami waves are responsible for their emplacement. In the equation developed by Noormets, hydrodynamic forces at the low submerged shoreline cliff are computed using design wave characteristics, based on linear wave theory and experimental results, which include also the local wave climate, nearshore bottom topography and initial fracturing of cliff rocks. More recently, research attention has shifted its focus to the role of impacting wave height compared to the wave length and to the wave period. Different theories have been proposed (Goto et al., 2007, 2009, 2010; Hansom et al., 2008; Imamura et al., 2008; Pignatelli et al., 2009; Nandasena et al., 2011), suggesting that in order to evaluate the wave impact on a rocky coast, these parameters should be considered all together.

The eastern coast of the island of Malta is characterised by the occurrence of deposits of anomalous calcareous boulders (Furlani et al., 2011; Mottershead et al., 2014; Causon Deguara, 2015). Their surface is frequently covered by biogenic encrustations, which indicate without any doubt that they were detached from the mid- or sublittoral zone.

The aims of this paper are to identify the physical processes responsible for the accumulation of the coastal boulders and to understand whether these boulders can be a potential geo-hazard for the low-lying rocky coasts of Malta.

\section{The study area}

The Maltese archipelago is located in the Sicily-Malta channel (central Mediterranean Sea, Fig. 1a), $90 \mathrm{~km}$ south of Sicily and $290 \mathrm{~km}$ north of Libyan coasts, and consists of three main islands, namely Malta $\left(245.7 \mathrm{~km}^{2}\right)$, Gozo $\left(67.1 \mathrm{~km}^{2}\right)$ and Comino $\left(2.8 \mathrm{~km}^{2}\right)$. From a geo-tectonic point of view, together with the Hyblean Plateau (SE Sicily), the archipelago belongs to the Pelagian Block (Grasso and Pedley, 1985), the northernmost sector of the African plate, mostly composed of foreland Neogene carbonate successions (Patacca et al., 1979). Eastwards, the Pelagian Block is bounded by the Malta Escarpment, a Mesozoic passive margin separating the continental domain from the oceanic crust of the Ionian Basin (Scandone et al., 1981; Makris et al., 1986). Since the middle Pleistocene, it has been locally reactivated by normal faulting (Argnani and Bonazzi, 2005), related to a regional WNW-ESE-oriented extension (Monaco et al., 1997; Bianca et al., 1999; Palano et al., 2012) (Fig. 1a). It is marked by a high level of crustal seismicity, producing earthquakes with intensities of up to XI-XII MCS and $M \sim 7$, such as the 1169, 1693 and 1908 events (Baratta, 1901; Postpischl, 1985; Boschi et al., 1995). 

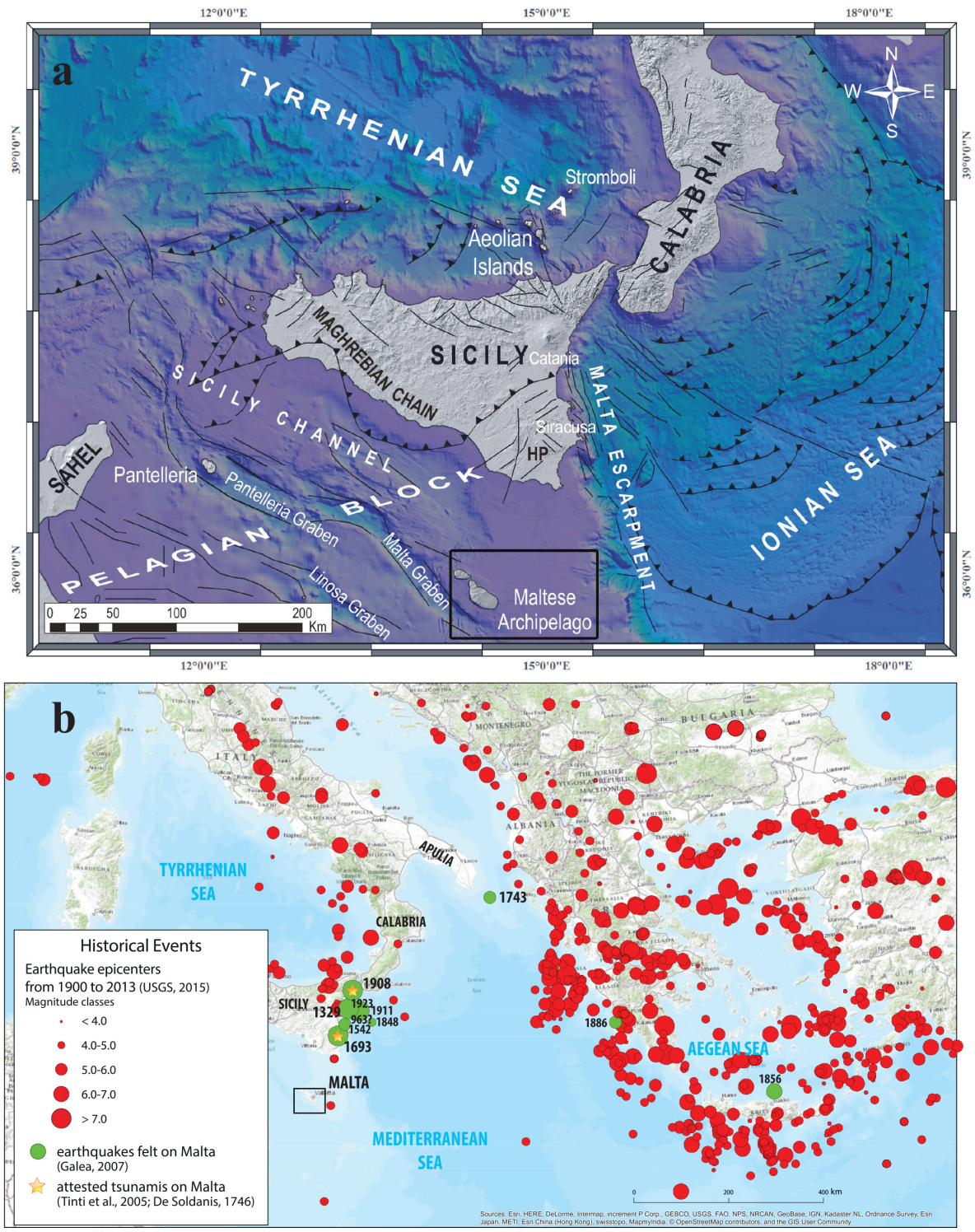

Figure 1. (a) Geodynamical setting of the Maltese archipelago (redrawn from Cultrera et al., 2015); (b) earthquakes felt on the island according to historical records (Galea, 2007) and the attested tsunamis on Malta according to De Soldanis (1746), Tinti et al. (2005) and Galea (2007), Bertolaso et al. (2008). Source: http://pubs.er.usgs.gov/publication/ofr20101083Q.

The Sicily-Malta channel underwent transtensional processes during the Neogene-Quaternary times, which led to the development of the Pantelleria, Linosa and Malta grabens, partially filled by Pliocene-Pleistocene sediments (Finetti, 1984). These structures are mostly bounded by NWSE-trending subvertical conjugate normal faults (Fig. 1a) whose activity would have reached the acme at approximately $5 \mathrm{Ma}$. Reactivation of the fault systems accommodated SW-NE extension in the late Quaternary (Corti et al., 2006; Catalano et al., 2009). As revealed by an available seismic database (INGV, http://emidius.mi.ingv.it/DBMI11), the above-cited structural features are a source of moderate seismicity, mostly located in the Linosa graben, with shal- low events $(h<25 \mathrm{~km})$ and a magnitude usually from 2 to 4 (Civile et al., 2008).

Several earthquake-generated tsunamis struck the Ionian coast of south-eastern Sicily and the Maltese archipelago in historical times such as in AD 1169, 1693 and 1908 (Tinti et al., 2004) (Fig. 1b).

According to published geological data and numerical modelling, the seismogenic source of these events should be located in the Strait of Messina and in the Ionian offshore (the Malta Escarpment) between the towns of Catania and Siracusa (e.g. Piatanesi and Tinti, 1998; Bianca et al., 1999; Monaco and Tortorici, 2000; Azzaro and Barbano, 2000). On the other hand, we must consider that many tsunamis that 
have occurred in the Mediterranean Sea have been generated in the Hellenic Arc area (i.e. Vött et al. (2010), Mastronuzzi et al. (2014) and references therein).

From a geomorphological point of view, the southern and western sectors of the Malta island are characterised by subvertical cliffs increasing in height northwards (mean heights of $100-120 \mathrm{~m}$ in the southern tract, and of $200-225 \mathrm{~m}$ along the western coast of the island, close to the Great Fault). Low-lying coasts are dominant on the eastern and northeastern parts of Malta, showing a system of surf bench and wave-cut platforms, some of which host boulder accumulations. This difference in the coastal morphology is linked to the development of a northeastwards tilting in response to the fault system activity, also responsible for the forcing of the surface waters in a WSW-ENE direction and the formation of NE-oriented fluvial valleys (Alexander, 1988; Biolchi et al., 2016). Wide sectors of NW coast of Malta are characterised by the presence of extensive landslides, mainly rock spreads and block slides (Devoto et al., 2012, 2013; Piacentini et al., 2015). These slow-moving landslides detach and move hundreds of limestone blocks from the karst plateaus towards the sea, forming peculiar coastal landforms named "rdum" by locals. Conversely, slow-moving landslides and related slope-failure accumulations are not common on the NE coast, although rock spreads and block slides have been recognised and investigated on the northern side of Xemxija Bay by Panzera et al. (2012).

The submerged landscape is mainly composed of flat to gently sloping terrain and comprises coastal landforms, such as fault-related scarps, palaeo shore platforms, palaeo shoreline deposits and slope-failure deposits, as well as terrestrial landforms, such as river valleys, alluvial plains, karstified limestone plateaus and sinkholes (Micallef et al., 2013).

The Maltese sedimentary succession mainly consists of pelagic limestones, clayey terrains and marls (Pedley et al., 1976, 1978). As illustrated in Fig. 2, it includes five formations: (1) Lower Coralline Limestone formation (LCL), consisting of late Oligocene (Brandano et al., 2009) bioclastic limestones; (2) Globigerina Limestone formation (GLO), late Oligocene to middle Miocene in age (Baldassini et al. (2013), Baldassini and Di Stefano (2015) and reference therein), consisting of pelagic marly limestones. It is subdivided, based on the occurrence of phosphoritic conglomerate beds (Baldassini and Di Stefano, 2015), into three members; (3) Blue Clay formation (BC), middle to late Miocene in age (Giannelli and Salvatorini, 1975; Hilgen et al., 2009), formed by silty marlstones; (4) Greensand formation, late Miocene (Tortonian) in age (Giannelli and Salvatorini, 1975), consisting of greenish marly/clayey glauconite sands and arenites; (5) Upper Coralline Limestone formation (UCL), late Miocene in age (Giannelli and Salvatorini, 1975), consisting of shallow-water bioclastic limestone deposits.

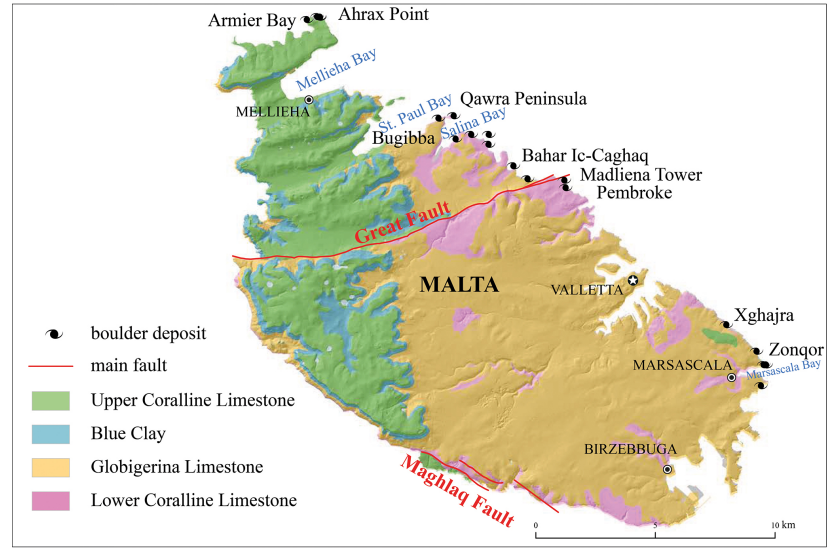

Figure 2. Geological map of Malta and location of the boulder deposits (redrawn from Oil Exploration Directorate, 1993; Devoto et al., 2012).

\section{Material and methods}

To identify and map the boulder accumulations, field surveys were carried out along the eastern low-lying coasts of Malta (Fig. 2). Some of these sites had already been recognised and categorised by various authors: Armier Bay by Furlani et al. (2011) and Biolchi et al. (2016); Ahrax Point, Pembroke and Xghajra by Mottershead et al. (2014); and Żonqor by Causon Deguara and Gauci (2014) and Causon Deguara (2015).

The most representative boulders, in terms of size, shape, distance from the coastline and presence of encrusted marine bioforms, were chosen for further analysis. The $77 \mathrm{se-}$ lected boulders included the largest observed blocks, slablike, roughly cubic and rectangular, as well as assembled and isolated ones.

To verify whether the detachment of the boulders is due to the storm wave regime of the area or a tsunami-related event, a hydrodynamic approach was applied in this study. In particular, we applied the well-known and accepted equations developed by Pignatelli et al. (2009), Nandasena et al. (2011) and Engel and May (2012), in order to calculate the minimum tsunami and storm wave heights required to detach a boulder from the coast edge or the nearshore environment (Table 1).

Direct measurements on each boulder were carried out to determine size, imbrication direction and distance from the shoreline, whilst the density was determined by means of the $N$-type Schmidt hammer (SH). The latter is a field instrument (Viles et al., 2011) to determine rock physical properties (intact rock strength and densities) by means of non-destructive testing (Yilmaz and Sendir, 2002). Katz et al. (2000) correlated an index named Hammer Rebound (HR), which is a function of the resistance of surface material hit by the SH to the density of the rocks. The boul- 
Table 1. Hydrodynamic equations ( $\mathrm{a}, \mathrm{b}$ and $\mathrm{c}$ for major, medium and minor axis respectively; $\rho_{\mathrm{b}}$ is the boulder density; $\rho_{\mathrm{w}}$ is the sea water density; $C_{\mathrm{L}}$ is the lift coefficient, which is $0.178 ; \theta$ is the bed slope angle; $\mu$ is the coefficient of static friction, which is $0.65 ; V$ is the boulder volume; $C_{\mathrm{D}}$ is the coefficient of drag, which is $1.95 ; q$ is the boulder area coefficient, which is 0.73 ).

\begin{tabular}{lll}
\hline Equation & Joint bounded scenario & $\begin{array}{l}\text { Submerged/subaerial } \\
\text { scenario (saltation) }\end{array}$ \\
\hline Pignatelli et al. (2009) Tsunami & $H_{\mathrm{T}}>\frac{0.5 c \cdot\left(\frac{\rho_{\mathrm{b}}}{\rho_{\mathrm{W}}}-1\right)}{C_{\mathrm{L}}}$ & - \\
\hline Pignatelli et al. (2009) Storm & $H_{\mathrm{S}}>\frac{2 c \cdot\left(\frac{\rho_{\mathrm{b}}}{\rho_{\mathrm{W}}}-1\right)}{C_{\mathrm{L}}}$ & - \\
Nandasena et al. (2011) Tsunami & $H_{\mathrm{T}}>\frac{0.5 c \cdot\left(\frac{\rho_{\mathrm{b}}}{\rho_{\mathrm{W}}}-1\right) \cdot(\cos \theta+\mu \operatorname{sen} \theta)}{C_{\mathrm{L}}}$ & $H_{\mathrm{T}} \geq \frac{0.5 c \cdot\left(\frac{\rho_{\mathrm{b}}}{\rho_{\mathrm{W}}}-1\right) \cdot \cos \theta}{C_{\mathrm{L}}}$ \\
\hline Nandasena et al. (2011) Storm & $H_{\mathrm{S}}>\frac{2 c \cdot\left(\frac{\rho_{\mathrm{b}}}{\rho_{\mathrm{W}}}-1\right) \cdot(\cos \theta+\mu \operatorname{sen} \theta)}{C_{\mathrm{L}}}$ & $H_{\mathrm{S}} \geq \frac{2 c \cdot\left(\frac{\rho_{\mathrm{b}}}{\rho_{\mathrm{W}}}-1\right) \cdot \cos \theta}{C_{\mathrm{L}}}$ \\
\hline Engel and May (2012) Tsunami & $H_{\mathrm{T}} \geq \frac{0.5 \mu V \rho_{\mathrm{b}}}{C_{\mathrm{D}}(a \cdot c \cdot q) \rho_{\mathrm{w}}}$ & - \\
\hline Engel and May (2012) Storm & $H_{\mathrm{S}} \geq \frac{2 \mu V \rho_{\mathrm{b}}}{C_{\mathrm{D}}(a \cdot c \cdot q) \rho_{\mathrm{w}}}$ & - \\
\hline
\end{tabular}

der density was associated to averaged HR value assigned to each block by means of Eq. (1):

$\rho=1308.2 \ln (\mathrm{HR})-2873.9$,

where $\rho$ is the density unit expressed in $\mathrm{kg} \mathrm{m}^{-3}$.

To avoid interferences due to the occurrence of discontinuities, fossils and weathering processes, we followed recommendations by the International Society for Rock Mechanics (ISRM). We took at least 10 single-impact readings for each block and averaged only the upper $50 \%$ for the determination of the boulder HR value, as suggested by the ISRM (1978). Moreover, in order to minimise deviations that would arise from an oblique impact (Aydin and Basu, 2005), we performed field tests, keeping the hammer axis perpendicular to the boulder surface (Table 2).

Given that the hydrodynamic approach also depends on the pre-transport environment, the most likely setting (submerged, subaerial, etc.) prior to transportation has been determined. Moreover, detailed submerged profiles of the five coastal sites have been constructed by carrying out direct underwater surveys, in order to verify a correlation between the submerged limestone features in the nearshore zones (such as fractures, rupture surfaces, detachment scarps, holes) and the quantity and shape of the deposited boulders.

The onshore boulders at each site were inspected to identify the presence of any biological encrustations, mainly of calcareous marine bioform type, which may remain attached to the boulders after emergence above sea level. When present on a boulder, such bioforms may serve as a strong indicator of the original location of the boulder in a submerged environment and which would die once the boulder is removed from its underwater environment. The taxa of these bioforms were identified in order to create an identity list of biota. The identity and ecology of the species served as a basis to draw inferences on the origin and history of the boulders and thus be of help to further corroborate the results obtained from hydrodynamic modelling.

Radiocarbon age dating of marine bioconcrections helped to reveal the deposition time frame. They were performed by the CeDaD Laboratory (Centro di Datazione e Diagnostica of the University of Salento, Italy). The calibration is based on the data set available on the website http://calib.qub.ac. $\mathrm{uk} / \mathrm{marine} / \mathrm{index}$.html and provides a choice between different procedures. We adopted the MMHM (i.e. mixed marine Northern Hemisphere) equation, with a $\delta R=59 \pm 40$ and $\delta R=71 \pm 50$, respectively obtained in the Tyrrhenian Sea on Arca tetragona species and Cerastoderma genus. We preferred to use the first value because of the greater ecological similarity, in particular for nourishment, with Vermetidae and Chthamalus. Indeed, the genus Arca lives fixed on the rocky bottoms and is characterised by suspension feeding behaviour. Conversely the genus Cerastoderma, although it shows suspension feeding behaviour, occupies the infaunal niches. Furthermore, it was considered that the percentage of carbonate origin besides continental starts from the value of $\delta^{13} \mathrm{C}$.

Finally, the collected field data were compared to the Maltese wave data and to historical catalogues of earthquakes and tsunamis (Tinti et al., 2004; Fago et al., 2014; Papadopoulos et al., 2014) in order to make a possible correlation with known events. With regards to local wave height parameters, the Malta Environment and Planning Authority (Malta Maritime Authority, 2003; Malta Environment and Planning Authority, 2007) provided a statistical study of two different areas of Malta (close to Bahar ić-Caghaq on the NE coast and close to Żonqor on the SE coast) from data measured during 2007, through which the inshore wave extremes have been estimated as 5.1-5.6 and 5.3-5.9 m respectively for a return period of 50 years and as 5.3-5.8 and 5.46.0 for a return period of 100 years at $20 \mathrm{~m}$ depth. A wave 
Table 2. $N$-type Schmidt Hammer $R$ values performed on boulder accumulations situated along the eastern coast of Malta. The densities of boulders were determined by the formula developed by Katz et al. (2000).

\begin{tabular}{|c|c|c|c|c|c|}
\hline $\begin{array}{l}\text { Boulder } \\
\text { no. }\end{array}$ & $\begin{array}{l}\text { Geological } \\
\text { formation }\end{array}$ & Location & Date & $\begin{array}{c}\text { Averaged } \\
\text { HR }\end{array}$ & $\begin{array}{c}\text { Density } \\
\left(\mathrm{kg} \mathrm{m}^{-3}\right)\end{array}$ \\
\hline $\mathrm{AB} 1$ & UCL & Armier Bay & 18 May 2014 & 35 & 1780 \\
\hline $\mathrm{AB} 2$ & UCL & Armier Bay & 18 May 2014 & 37 & 1850 \\
\hline $\mathrm{AB} 3$ & UCL & Armier Bay & 18 May 2014 & 31 & 1620 \\
\hline $\mathrm{AB} 4$ & UCL & Armier Bay & 18 May 2014 & 36 & 1810 \\
\hline AB5 & UCL & Armier Bay & 18 May 2014 & 32 & 1660 \\
\hline MAS new & UCL & Armier Bay & 18 May 2014 & 30 & 1580 \\
\hline $\mathrm{AB} 7$ & UCL & Armier Bay & 18 May 2014 & 32 & 1660 \\
\hline AA1 & UCL & Ahrax Point & 30 Jan 2015 & 26 & 1390 \\
\hline AA9 & UCL & Ahrax Point & 30 Jan 2015 & 31 & 1620 \\
\hline AA11 & UCL & Ahrax Point & 30 Jan 2015 & 32 & 1660 \\
\hline AA 12 & UCL & Ahrax Point & 30 Jan 2015 & 43 & 2050 \\
\hline AA14 & UCL & Ahrax Point & 30 Jan 2015 & 32 & 1660 \\
\hline B1 & LCL & Bahar ić-Ċaghaq & 18 May 2014 & 33 & 1700 \\
\hline $\mathrm{BIC}$ & GLO & Bahar ić-Caghaq & 30 Jan 2015 & 26 & 1390 \\
\hline QW1 & LCL & Qawra peninsula & 29 Jan 2015 & 15 & 1670 \\
\hline QW2 & LCL & Qawra peninsula & 29 Jan 2015 & 34 & 1740 \\
\hline QW3 & LCL & Qawra peninsula & 29 Jan 2015 & 38 & 1880 \\
\hline LB1 & LCL & Bugibba & 29 Jan 2015 & 33 & 1700 \\
\hline LB2 & LCL & Bugibba & 30 Jan 2015 & 41 & 1980 \\
\hline LB3 & LCL & Bugibba & 30 Jan 2015 & 44 & 2080 \\
\hline LB4 & LCL & Bugibba & 30 Jan 2015 & 31 & 1620 \\
\hline LB5 & LCL & Bugibba & 30 Jan 2015 & 37 & 1850 \\
\hline LB6 & LCL & Bugibba & 30 Jan 2015 & 42 & 2020 \\
\hline LB7 & LCL & Bugibba & 30 Jan 2015 & 41 & 1980 \\
\hline LB8 & LCL & Bugibba & 30 Jan 2015 & 34 & 1740 \\
\hline LB9 & LCL & Bugibba & 30 Jan 2015 & 33 & 1700 \\
\hline LB10 & LCL & Bug̣ibba & 30 Jan 2015 & 43 & 2050 \\
\hline $\mathrm{P} 1$ & LCL & Pembroke & 30 Jan 2015 & 50 & 2240 \\
\hline P3 & LCL & Pembroke & 30 Jan 2015 & 48 & 2190 \\
\hline P4 & LCL & Pembroke & 30 Jan 2015 & 44 & 2080 \\
\hline P7 & LCL & Pembroke & 30 Jan 2015 & 44 & 2080 \\
\hline $\mathrm{Z} 1$ & LCL & Żonqor & 30 Aug 2014 & 29 & 1530 \\
\hline $\mathrm{Z} 2$ & GLO & Żonqor & 30 Aug 2014 & 33 & 1700 \\
\hline $\mathrm{Z3}$ & GLO & Żonqor & 30 Aug 2014 & 33 & 1700 \\
\hline $\mathrm{Z} 4$ & GLO & Żonqor & 30 Aug 2014 & 34 & 1739 \\
\hline $\mathrm{Z} 5$ & GLO & Żonqor & 30 Aug 2014 & 34 & 1739 \\
\hline Z6 & GLO & Żonqor & 30 Aug 2014 & 34 & 1739 \\
\hline $\mathrm{Z7}$ & GLO & Żonqor & 30 Aug 2014 & 33 & 1700 \\
\hline $\mathrm{Z} 8$ & GLO & Żonqor & 30 Aug 2014 & 38 & 1884 \\
\hline Z9 & GLO & Żonqor & 30 Aug 2014 & 34 & 1739 \\
\hline Z10 & GLO & Żonqor & 30 Aug 2014 & 34 & 1739 \\
\hline Z11 & GLO & Żonqor & 30 Aug 2014 & 34 & 1739 \\
\hline Z12 & GLO & Żonqor & 30 Aug 2014 & 28 & 1485 \\
\hline Z13 & GLO & Żonqor & 30 Aug 2014 & 37 & 1850 \\
\hline Z14 & Mixed & Żonqor & 30 Aug 2014 & 35 & 1777 \\
\hline Z15 & Mixed & Żonqor & 30 Aug 2014 & 40 & 1752 \\
\hline
\end{tabular}

height of almost $7 \mathrm{~m}$ was recorded on 15 October 2007 during a very strong storm.

Drago et al. (2013) provided an analysis of the Maltese waves by taking into account wave data over a span of 5 years (2007-2011), measured by a buoy located $2 \mathrm{~km}$ offshore from the NW coast of Gozo. The highest wave was registered on 6 January 2012 with a height of $7.46 \mathrm{~m}$.

This value, associated with a wave period of $9 \mathrm{~s}$, has been used to apply the Sunamura and Horikawa (1974) equation which calculates the wave height at breaking point $\left(H_{\mathrm{b}}\right)$ of a 
coastal area:

$$
\frac{H_{\mathrm{b}}}{H_{0}}=(\tan \beta)^{0.2} \cdot{\frac{H_{0}}{L_{0}}}^{-0.25},
$$

where $H_{\mathrm{b}}$ is the breaking wave height, $H_{0}$ is the wave height in deep water, $\beta$ is the slope of the sea bottom in the coastal area and $L_{0}$ the wave length in deep water $\left(L_{0}=\frac{g T^{2}}{2 \pi} ;\right.$ Sarpkaya and Isaacson, 1981).

The resultant breaking wave height $H_{\mathrm{b}}$ for the five study areas were as follows: $6.6 \mathrm{~m}$ at Armier Bay, $9.4 \mathrm{~m}$ at Ahrax Point, $8.7 \mathrm{~m}$ at Bugibba, $7.1 \mathrm{~m}$ at Qawra peninsula, $8.0 \mathrm{~m}$ at Bahar ić-Caghaq, $10.2 \mathrm{~m}$ at Pembroke and $8.4 \mathrm{~m}$ at Żonqor. These values have been considered as thresholds to distinguish storm waves from tsunami waves.

\section{Results}

\subsection{Armier Bay and Ahrax Point}

This boulder site was identified for the first time by Furlani et al. (2011) and was recently studied by Mottershead et al. (2014) and Biolchi et al. (2016) and is located in the north-eastern sector of the island (Fig. 2), which is exposed to winds blowing from west to north-north-west.

From a geomorphological point of view, this part of the coast can be defined as rocky low-lying coast, with an average slope of 5-6 (Said and Schembri, 2010; Fig. 3b).

The coast is entirely composed of Upper Coralline Limestone. The bedding is subhorizontal and has an average thickness of $50 \mathrm{~cm}$. The boulders, ranging in size from decimetric to metric, are clustered in the central part of the deposit at a distance from the coastline varying from 10 to $30 \mathrm{~m}$ (Fig. 3a and b). Away from the central outcrop, the boulders are more scattered in an isolated manner and their size decreases with increasing distance from sea level. The grain size distribution of boulders shows an exponential landward fining trend.

The boulders reach inland limits of up to $50 \mathrm{~m}$ away from the shoreline, at elevations of $8 \mathrm{~m}$ a.s.l. (above sea level). More than 100 boulders are counted as total deposits (Mottershead et al., 2014; Fig. 3c). Some boulders are imbricated toward $\mathrm{NE}$ and are indicative of the flow direction from which they are deposited, with an orientation of the long axis toward WNW. With regards to their shape, blocks in rectangular forms are more abundant as a result of local discontinuities and quarrying activity on blocks along the bedding planes, with the latter corresponding to the $c$ axis of the boulders. On the exposed surface of some boulders, small karst features, such as solution pools, small pinnacles and microrills, were observed.

Underwater surveys uncovered a submerged scenario characterised by isolated boulders, both with fresh edges and/or covered by algae and populated by marine organisms, niches and fresh detachment scarps (Fig. 3d). The sea bottom is similar to the subaerial geomorphological setting, be-
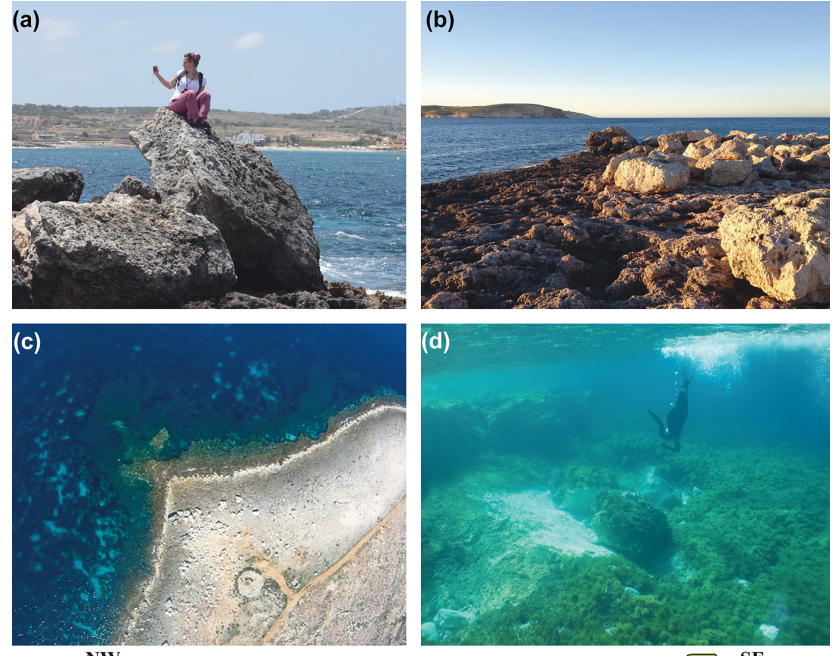

(e)
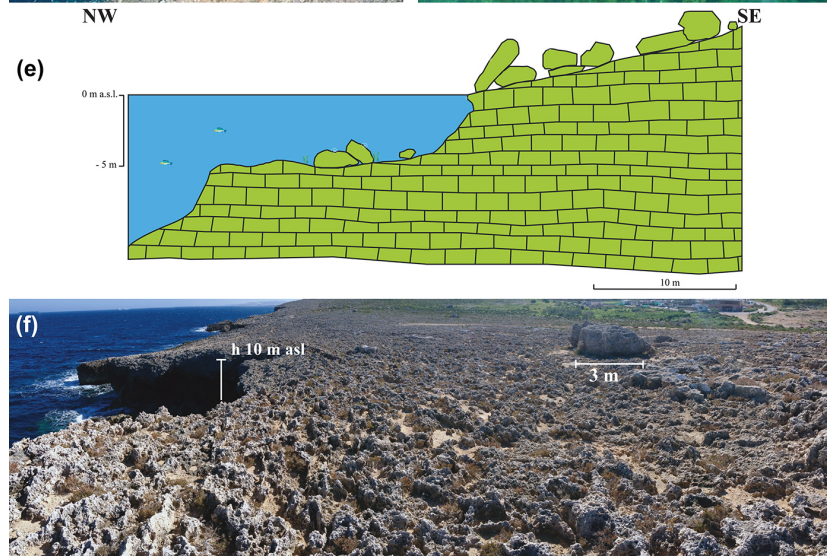

Figure 3. (a) Boulder AB1 at Armier Bay; (b) boulder deposit at Armier Bay; (c) view of the Armier Bay boulder deposit from a UAV (unmanned aerial vehicle); (d) submerged isolated boulders; (e) reconstruction of the submerged environment at Armier Bay; (f) cliff top storm deposits at Ahrax Point.

ing characterised by a gentle sloping platform, interrupted by small scarps which correspond to the bedding planes (Fig. 3e).

A number of boulders at Armier Bay have remains of marine organisms. The most common were shells of the vermetid molluscs Dendropoma petraeum and Vermetus triquetrus (triqueter?), together with calcareous Rhodophyta. These two vermetid species are typical of the lower midlittoral to infralittoral transition, and thus indicate that the boulders were at some point present at approximately mean sea level. This was confirmed with the presence of barnacle shells belonging to the family Chthamalidae on one of the boulders; such barnacles normally occur just above mean sea level. Shells of the vermetid gastropod Thylacodes arenarius and the skeletal remains of a coral belonging to the genus Caryophyllia were present on one of the smaller boulders. Both organisms occur in the shallow infralittoral transition, suggesting that this specific boulder was at one point fully 
submerged, probably at a depth of $\sim 0.5-5.0 \mathrm{~m}$. On the other hand, there were numerous boulders at Armier Bay without any adherent bioencrustations; however, this absence does not necessarily imply a non-marine origin, since only encrusting organisms cemented to the surface of the boulders, are likely to remain in place after emergence. Non-calcareous bioforms are very easily eroded away, leaving no trace on the boulders. The proposed scenario is a joint bounded submerged one.

The results of the hydrodynamic equations and those of radiocarbon dating are listed in Tables 3 and 4, respectively. According to the equations of Nandasena et al. (2011) and Pignatelli et al. (2009), only four boulders seem to require storm waves with heights which exceed the local values, given that they range from above $7 \mathrm{~m}$ to approximately $13 \mathrm{~m}$. On the other hand, with the Engel and May (2012) approach, the wave heights are markedly lower $(1.7-2.5 \mathrm{~m})$. The tsunami wave heights are however comparable with those observed both during the 1908 event (Guidoboni and Mariotti, 2008) and also by Tinti et al. (2005). The rest of the values obtained with the hydrodynamic equations are comparable with the Maltese storm waves: $2.27-6.34 \mathrm{~m}$ (with Nandasena et al., 2011), 2.15-5.99 m (with Pignatelli et al., 2009) and 1.31-4.80 m (with Engel and May, 2012).

With regards to radiocarbon dating results, among the boulders that exceed the estimated storm wave height of $6.6 \mathrm{~m}$, three of them (AB4, AB7 and $\mathrm{AB} 5)$ recorded ages that may potentially align with historical tsunami events: $938 \pm 70$ (AB4), 869 \pm 75 (AB5) and $122 \pm 72$ (AB7). The other dated boulders, such as AB1 (514 $\pm 104 \mathrm{BC})$, AB2 (1298 \pm 46$), A B 6(1290 \pm 54)$ and Q2 (1384 \pm 47$)$, seem to have required wave heights comparable both to the storm regime and the historical known tsunami waves. On the other hand, the radiocarbon dating performed on the C16 boulder confirms its origin to a storm-related event.

Moving eastwards, toward Ahrax Point, tens of boulders have been deposited at relatively higher elevations. They actually represent the boulder site with the highest elevation point across the island of Malta. Some of them are scattered and isolated (Fig. 3f). Conversely, the majority are gathered and disposed to forming a sort of storm berm, which is aligned in the NW direction, at a distance from the coast varying from 10 to $40 \mathrm{~m}$. Their maximum elevation is about $20 \mathrm{~m}$. Locally, the boulders are imbricated toward NE.

At this site, the boulders do not have any marine encrustations and seem to have been detached from the top of the nearby cliff, which is deeply eroded and indented. A detachment scarp, located at an elevation of $10 \mathrm{~m}$ a.s.l., seems to indicate a subaerial process-driven scenario. It is possible that these blocks correspond to cliff-top storm deposits, very similar to those characterised by some small karst pools, including sand with marine shells, described by Hall et al. (2006). As a matter of fact, the underwater surveys did not reveal scarps, pluck holes or fractured rocky outcrops.
Contrary to the hypothesis proposed by Mottershead et al. (2014), we suggest a storm wave higher than $10 \mathrm{~m}$, which was amplified by the topography of the sea bottom, as the responsible mechanism for the boulders' detachment.

\subsection{Qawra-Bugibba}

The coast between Bugibba and Qawra stretches further east from Mellieha Bay. This coastal area is exposed to strong winds and high waves triggered by the north-easterly storms known locally as "Grigal". The cause of such large waves is the long fetch that stretches all the way to the Ionian Sea of Greece. These violent storms generally last $24 \mathrm{~h}$, whilst in the successive days the sea conditions are characterised by large swell conditions, which continue to pound on the coastline from the same north-easterly direction.

The rocky coastline of Bugibba consists of Lower Coralline Limestone, which outcrops at sea level as a subhorizontal terrace, and connects with on overlying steep cliff, 3-5 m high, of Lower Globigerina Limestone.

The boulders originate from both lithologies and are scattered, locally overlying each other, on the terrace, which in this area has an elevation of about $10 \mathrm{~m}$ a.s.l. (Fig. 4a). They are mainly rectangular, as a result of the orientation of three discontinuity sets, which act as lines of weakness on the terrace surface. Their sizes vary from decimetric to metric, with an $a$ axis ranging from 1 to $2.5 \mathrm{~m}$, while the $c$ axis (which corresponds mainly with the bed thicknesses) measures from 0.5 to $1 \mathrm{~m}$. The average direction of the long axis of the largest boulders is NW. The majority of these boulders have collapsed from the top of the slope, leaving niches and detachment scarps on the slope. Other boulders originate from the sea, as evidenced by the presence of marine encrustations, including an aggregation of the vermetid mollusc D. petraeum as well as serpulid tubes (i.e. boulder Qa2). The presence of a vermetid crust at the surface, with a main discontinuity plane on the opposite face of the boulders, indicates that these deposits originally formed part of the coastline, with their surface at approximately mean sea level. They were eventually detached through wave undercutting and transported to their present location. Along the coastline, fresh detachment surfaces are clearly visible, both above and below sea level, as evidenced by direct underwater observations and unmanned aerial vehicle (UAV) images, which show pluck holes and isolated submerged boulders (Fig. 4b). Fresh impact marks, both on the rock surface and on boulders, can be observed. For these boulders, a joint bounded submerged scenario is also being proposed.

According to the results of the hydrodynamic equations of Nandasena et al. (2011) and Pignatelli et al. (2009) (Table 3), within the 10 measured blocks, 4 of them have required waves higher than $8.7 \mathrm{~m}$ to be detached from the coastal edge or from the nearshore bottom. On the contrary, according to the Engel and May (2012) equation, the values are lower (2-4.5 m). Among these boulders, the serpulid 
Table 3. Physical parameters of the boulders and results of the application of the hydrodynamic equations provided by Nandasena et al. (2011), Pignatelli et al. (2009) and Engel and May (2012). The dated boulders are reported in bold characters.

\begin{tabular}{|c|c|c|c|c|c|c|c|c|c|c|c|c|c|}
\hline Site & Boulder & $\begin{array}{l}\operatorname{ax} a \\
(\mathrm{~m})\end{array}$ & $\begin{array}{l}\operatorname{ax} b \\
(\mathrm{~m})\end{array}$ & $\begin{array}{l}\operatorname{ax} c \\
(\mathrm{~m})\end{array}$ & $\begin{array}{r}\text { Volume } \\
\left(\mathrm{m}^{3}\right)\end{array}$ & $\begin{array}{l}\text { Density } \\
\left(\mathrm{g} \mathrm{cm}^{-3}\right)\end{array}$ & $\begin{array}{r}\text { Mass } \\
(\mathrm{t})\end{array}$ & $\begin{array}{l}\text { Nandasena } \\
\text { tsunami } \\
\text { (m) }\end{array}$ & $\begin{array}{l}\text { Nandasena } \\
\text { storm } \\
\text { (m) }\end{array}$ & $\begin{array}{l}\text { Pignatelli } \\
\text { tsunami } \\
\text { (m) }\end{array}$ & $\begin{array}{r}\text { Pignatelli } \\
\text { storm } \\
(\mathrm{m})\end{array}$ & $\begin{array}{c}\text { Engel } \\
\text { tsunami } \\
(\mathrm{m})\end{array}$ & $\begin{array}{c}\text { Engel } \\
\text { storm } \\
(\mathrm{m})\end{array}$ \\
\hline \multirow{23}{*}{ 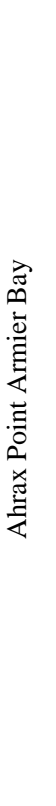 } & AA1 & 4.1 & 2.4 & 1.1 & 10.82 & 1.39 & 15.02 & 1.18 & 4.71 & 1.11 & 4.46 & 0.80 & 3.21 \\
\hline & AA2 & 2.8 & 1.2 & 1.1 & 3.70 & 1.70 & 6.28 & 2.18 & 8.71 & 2.06 & 8.24 & 0.49 & 1.97 \\
\hline & AA3 & 1.8 & 0.8 & 0.8 & 1.15 & 1.70 & 1.96 & 1.58 & 6.34 & 1.50 & 5.99 & 0.33 & 1.31 \\
\hline & AA4 & 3 & 2.2 & 0.65 & 4.29 & 1.70 & 7.29 & 1.29 & 5.15 & 1.22 & 4.87 & 0.90 & 3.61 \\
\hline & AA5 & 2.25 & 1.9 & 0.3 & 1.28 & 1.70 & 2.18 & 0.59 & 2.38 & 0.56 & 2.25 & 0.78 & 3.11 \\
\hline & AA7 & 1.7 & 1 & 0.8 & 1.36 & 1.70 & 2.31 & 1.58 & 6.34 & 1.50 & 5.99 & 0.41 & 1.64 \\
\hline & AA8 & 2 & 1 & 0.5 & 1.00 & 1.70 & 1.70 & 0.99 & 3.96 & 0.94 & 3.75 & 0.41 & 1.64 \\
\hline & AA9 & 2 & 1.2 & 0.45 & 1.08 & 1.62 & 1.75 & 0.78 & 3.13 & 0.74 & 2.96 & 0.47 & 1.87 \\
\hline & AA10 & 9.5 & 2 & 1.3 & 24.70 & 1.7 & 41.99 & 2.61 & 9.70 & 2.43 & 9.74 & 0.82 & 3.28 \\
\hline & AA11 & 3 & 1.5 & 0.9 & 4.05 & 1.66 & 6.72 & 2.46 & 6.32 & 1.59 & 6.35 & 0.60 & 2.40 \\
\hline & AA12 & 2.6 & 1.7 & 1.5 & 6.63 & 2.047 & 13.57 & 3.94 & 16.91 & 4.24 & 16.97 & 0.84 & 3.36 \\
\hline & AA14 & 2.9 & 1.8 & 0.9 & 4.70 & 1.66 & 7.80 & 2.46 & 6.32 & 1.59 & 6.35 & 0.72 & 2.88 \\
\hline & AA15 & 1.1 & 1 & 0.3 & 0.33 & 1.7 & 0.56 & 2.61 & 2.24 & 0.56 & 2.25 & 0.41 & 1.64 \\
\hline & AB1 & 4.2 & 2.8 & 0.5 & 5.88 & 1.78 & 10.45 & 1.10 & 4.41 & 1.04 & 4.17 & 1.20 & 4.80 \\
\hline & AB2 & 3.5 & 1.6 & 0.55 & 3.08 & 1.85 & 5.70 & 1.33 & 5.32 & 1.26 & 5.03 & 0.71 & 2.85 \\
\hline & $\mathrm{AB} 3$ & 2 & 1.6 & 0.8 & 2.56 & 1.62 & 4.14 & 1.39 & 5.57 & 1.32 & 5.27 & 0.62 & 2.50 \\
\hline & AB4 & 1.9 & 1.4 & 1.4 & 3.72 & 1.81 & 6.76 & 3.24 & 12.95 & 3.06 & 12.24 & 0.61 & 2.45 \\
\hline & AB6 & 1.6 & 1.2 & 0.5 & 0.96 & 1.70 & 1.63 & 0.99 & 3.96 & 0.94 & 3.75 & 0.49 & 1.97 \\
\hline & AB7 & 3.4 & 1.6 & 1.15 & 6.26 & 1.70 & 10.64 & 2.28 & 9.11 & 2.15 & 8.61 & 0.66 & 2.62 \\
\hline & C16 & 0.9 & 0.8 & 0.25 & 0.18 & 1.80 & 0.32 & 0.57 & 2.27 & 0.54 & 2.15 & 0.35 & 1.39 \\
\hline & C82/AB5 & 2.56 & 1.06 & 0.92 & 2.50 & 1.70 & 4.24 & 1.82 & 7.29 & 1.72 & 6.89 & 0.43 & 1.74 \\
\hline & new & 2.39 & 1.69 & 0.82 & 3.31 & 1.58 & 5.22 & 1.33 & 5.31 & 1.26 & 5.02 & 0.64 & 2.57 \\
\hline & Q2 & 0.75 & 0.55 & 0.5 & 0.21 & 1.70 & 0.35 & 0.99 & 3.96 & 0.94 & 3.75 & 0.23 & 0.90 \\
\hline \multirow{14}{*}{ 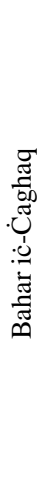 } & B1 & 2.3 & 1.85 & 0.6 & 2.55 & 1.70 & 4.34 & 1.14 & 4.55 & 1.12 & 4.49 & 0.76 & 3.03 \\
\hline & B2 & 4.35 & 3.65 & 0.4 & 6.35 & 1.80 & 11.43 & 0.87 & 3.48 & 0.86 & 3.44 & 1.58 & 6.33 \\
\hline & B3 & 2.4 & 1.8 & 0.55 & 2.38 & 1.80 & 4.28 & 1.20 & 4.78 & 1.18 & 4.73 & 0.78 & 3.12 \\
\hline & B4 & 2.6 & 1.7 & 0.7 & 3.09 & 1.80 & 5.57 & 1.52 & 6.09 & 1.50 & 6.01 & 0.74 & 2.95 \\
\hline & B5 & 2.15 & 1.93 & 0.7 & 2.90 & 1.80 & 5.23 & 1.52 & 6.09 & 1.50 & 6.01 & 0.84 & 3.35 \\
\hline & B6 & 2 & 1.5 & 0.55 & 1.65 & 1.80 & 2.97 & 1.20 & 4.78 & 1.18 & 4.73 & 0.65 & 2.60 \\
\hline & B7 & 2.3 & 1.6 & 0.36 & 1.32 & 1.80 & 2.38 & 0.78 & 3.13 & 0.77 & 3.09 & 0.69 & 2.78 \\
\hline & B8 & 3 & 2.4 & 1 & 7.20 & 1.80 & 12.96 & 2.17 & 8.70 & 2.15 & 8.59 & 1.04 & 4.17 \\
\hline & B9 & 3.3 & 1.65 & 0.6 & 3.27 & 1.39 & 4.53 & 0.66 & 2.62 & 0.61 & 2.43 & 0.55 & 2.21 \\
\hline & B10 & 3.1 & 1.6 & 0.6 & 2.98 & 1.39 & 4.13 & 0.66 & 2.62 & 0.61 & 2.43 & 0.54 & 2.14 \\
\hline & B11 & 3.3 & 1.8 & 0.69 & 4.10 & 1.39 & 5.69 & 0.75 & 3.01 & 0.70 & 2.80 & 0.60 & 2.41 \\
\hline & B12 & 3.1 & 2.35 & 0.5 & 3.64 & 1.39 & 5.06 & 0.55 & 2.18 & 0.51 & 2.03 & 0.79 & 3.15 \\
\hline & B13 & 4.3 & 3.4 & 0.7 & 10.23 & 1.39 & 14.20 & 0.76 & 3.06 & 0.71 & 2.84 & 1.14 & 4.55 \\
\hline & B14 & 3.2 & 2.1 & 1.1 & 7.39 & 1.39 & 10.26 & 1.20 & 4.81 & 1.11 & 4.46 & 0.70 & 2.81 \\
\hline \multirow{14}{*}{ 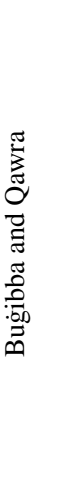 } & LB1 & 4 & 2 & 1.2 & 9.60 & 1.70 & 16.32 & 2.44 & 9.78 & 2.25 & 8.99 & 0.82 & 3.28 \\
\hline & LB2 & 2.9 & 1.65 & 1.05 & 5.02 & 1.98 & 9.97 & 3.03 & 12.13 & 2.79 & 11.15 & 0.79 & 3.16 \\
\hline & LB3 & 2.6 & 1.8 & 1.1 & 5.15 & 2.08 & 10.69 & 3.54 & 14.17 & 3.20 & 12.81 & 0.90 & 3.60 \\
\hline & LB4 & 3.3 & 2.8 & 0.6 & 5.54 & 1.62 & 8.97 & 1.09 & 4.37 & 0.99 & 3.95 & 1.09 & 4.37 \\
\hline & LB6 & 2.016 & 1.12 & 0.35 & 0.79 & 1.85 & 1.46 & 0.89 & 3.54 & 0.80 & 3.20 & 0.50 & 2.00 \\
\hline & LB7 & 1.984 & 1.8 & 1.1 & 3.93 & 2.02 & 7.92 & 3.34 & 13.35 & 3.02 & 12.07 & 0.87 & 3.50 \\
\hline & LB8 & 1.739 & 1.6 & 0.85 & 2.37 & 1.74 & 4.11 & 1.86 & 7.45 & 1.68 & 6.73 & 0.67 & 2.68 \\
\hline & LB9 & 2.5 & 2.15 & 0.8 & 4.30 & 1.70 & 7.31 & 1.63 & 6.52 & 1.50 & 5.99 & 0.88 & 3.52 \\
\hline & LB10 & 2.4 & 2.3 & 0.5 & 2.76 & 2.05 & 5.65 & 1.50 & 5.98 & 1.41 & 5.66 & 1.13 & 4.54 \\
\hline & Qa1 & 1.8 & 1.4 & 1.3 & 3.28 & 1.80 & 5.90 & 2.95 & 11.81 & 2.79 & 11.17 & 0.61 & 2.43 \\
\hline & Qa2 & 2.2 & 1.2 & 0.65 & 1.72 & 1.80 & 3.09 & 1.54 & 6.18 & 1.40 & 5.58 & 0.52 & 2.08 \\
\hline & Qa3 & 1.5 & 1.5 & 0.7 & 1.58 & 1.85 & 2.91 & 1.77 & 7.08 & 1.60 & 6.40 & 0.67 & 2.68 \\
\hline & qawra_2 & 2 & 1.05 & 0.6 & 1.26 & 1.74 & 2.19 & 1.24 & 4.97 & 1.19 & 4.75 & 0.44 & 1.76 \\
\hline & qawra_3 & 2.3 & 1.5 & 1.1 & 3.80 & 1.88 & 7.15 & 2.74 & 10.95 & 2.62 & 10.47 & 0.68 & 2.72 \\
\hline
\end{tabular}


Table 3. Continued.

\begin{tabular}{|c|c|c|c|c|c|c|c|c|c|c|c|c|c|}
\hline Site & Boulder & $\begin{array}{l}\text { ax } a \\
\text { (m) }\end{array}$ & $\begin{array}{l}\operatorname{ax} b \\
(\mathrm{~m})\end{array}$ & $\begin{array}{l}\operatorname{ax} c \\
(\mathrm{~m})\end{array}$ & $\begin{array}{r}\text { Volume } \\
\left(\mathrm{m}^{3}\right)\end{array}$ & $\begin{array}{l}\text { Density } \\
\left(\mathrm{g} \mathrm{cm}^{-3}\right)\end{array}$ & $\begin{array}{r}\text { Mass } \\
(\mathrm{t})\end{array}$ & $\begin{array}{l}\text { Nandasena } \\
\text { tsunami } \\
\text { (m) }\end{array}$ & $\begin{array}{l}\text { Nandasena } \\
\text { storm } \\
\text { (m) }\end{array}$ & $\begin{array}{l}\text { Pignatelli } \\
\text { tsunami } \\
\text { (m) }\end{array}$ & $\begin{array}{r}\text { Pignatelli } \\
\text { storm } \\
(\mathrm{m})\end{array}$ & $\begin{array}{c}\text { Engel } \\
\text { tsunami } \\
(\mathrm{m})\end{array}$ & $\begin{array}{c}\text { Engel } \\
\text { storm } \\
(\mathrm{m})\end{array}$ \\
\hline \multirow{10}{*}{ 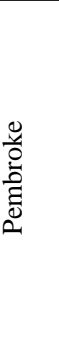 } & P16 & 2 & 1.3 & 0.4 & 1.04 & 1.80 & 1.87 & 0.90 & 3.60 & 0.86 & 3.44 & 0.56 & 2.26 \\
\hline & P1 & 2.55 & 1.2 & 0.6 & 1.84 & 2.24 & 4.12 & 2.18 & 8.72 & 2.02 & 8.09 & 0.65 & 2.60 \\
\hline & $\mathrm{P} 2$ & 2 & 1.5 & 0.65 & 1.95 & 2.20 & 4.29 & 2.28 & 9.11 & 2.11 & 8.45 & 0.80 & 3.18 \\
\hline & P3 & 2.85 & 2.7 & 0.8 & 6.16 & 2.19 & 13.48 & 2.78 & 11.11 & 2.58 & 10.31 & 1.43 & 5.70 \\
\hline & P4 & 2.5 & 1.8 & 0.7 & 3.15 & 2.08 & 6.54 & 2.20 & 8.79 & 2.04 & 8.15 & 0.90 & 3.60 \\
\hline & P5 & 2.8 & 1.5 & 0.7 & 2.94 & 2.08 & 6.11 & 2.20 & 8.79 & 2.04 & 8.15 & 0.75 & 3.00 \\
\hline & P6 & 2.4 & 2.1 & 0.7 & 3.53 & 2.08 & 7.33 & 2.20 & 8.79 & 2.04 & 8.15 & 1.05 & 4.21 \\
\hline & P7 & 2.55 & 1.4 & 0.5 & 1.79 & 2.08 & 3.71 & 1.52 & 6.09 & 1.46 & 5.82 & 0.70 & 2.80 \\
\hline & P9 & 2.55 & 1.5 & 0.6 & 2.30 & 2.08 & 4.77 & 1.83 & 7.31 & 1.75 & 6.99 & 0.75 & 3.00 \\
\hline & $\mathrm{P} 10$ & 2.55 & 1.5 & 0.35 & 1.34 & 2.08 & 2.78 & 1.07 & 4.26 & 1.02 & 4.08 & 0.75 & 3.00 \\
\hline \multirow{15}{*}{ 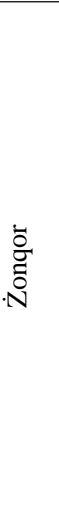 } & $\mathbf{Z 1}$ & 2 & 1.7 & 0.7 & 2.38 & 1.53 & 3.64 & 1.08 & 4.32 & 0.99 & 3.94 & 0.63 & 2.51 \\
\hline & $\mathrm{Z} 2$ & 2.3 & 1.3 & 0.8 & 2.39 & 1.70 & 4.07 & 1.64 & 6.57 & 1.50 & 5.99 & 0.53 & 2.13 \\
\hline & $\mathrm{Z} 3$ & 2.8 & 2.2 & 0.8 & 4.93 & 1.70 & 8.38 & 1.57 & 6.27 & 1.50 & 5.99 & 0.90 & 3.61 \\
\hline & Z4 & 2 & 1.2 & 0.4 & 0.96 & 1.74 & 1.67 & 0.83 & 3.32 & 0.79 & 3.17 & 0.50 & 2.01 \\
\hline & Z5 & 2.3 & 0.7 & 0.5 & 0.81 & 1.74 & 1.40 & 1.04 & 4.14 & 0.99 & 3.96 & 0.29 & 1.17 \\
\hline & Z6 & 4.35 & 3 & 0.7 & 9.14 & 1.74 & 15.89 & 1.49 & 5.98 & 1.39 & 5.54 & 1.26 & 5.03 \\
\hline & $\mathrm{Z7}$ & 8.5 & 4 & 1.2 & 40.80 & 1.70 & 69.36 & 2.42 & 9.69 & 2.25 & 8.99 & 1.64 & 6.56 \\
\hline & Z8 & 3 & 1.1 & 0.3 & 0.99 & 1.88 & 1.87 & 0.76 & 3.05 & 0.71 & 2.86 & 0.50 & 2.00 \\
\hline & $\mathrm{Z9}$ & 2.5 & 1.2 & 1.1 & 3.30 & 1.74 & 5.74 & 2.33 & 9.30 & 2.18 & 8.71 & 0.50 & 2.01 \\
\hline & $\mathrm{Z} 10$ & 3.3 & 2.2 & 0.7 & 5.08 & 1.74 & 8.84 & 1.48 & 5.92 & 1.39 & 5.54 & 0.92 & 3.69 \\
\hline & Z11 & 3.5 & 2.1 & 1.5 & 11.03 & 1.74 & 19.17 & 3.17 & 12.68 & 2.97 & 11.88 & 0.88 & 3.52 \\
\hline & $\mathrm{Z} 12$ & 2.2 & 1.45 & 0.6 & 1.91 & 1.49 & 2.84 & 0.83 & 3.31 & 0.77 & 3.07 & 0.52 & 2.08 \\
\hline & Z13 & 2.8 & 1.1 & 1 & 3.08 & 1.85 & 5.70 & 2.46 & 9.85 & 2.29 & 9.14 & 0.49 & 1.96 \\
\hline & Z14 & 4.6 & 2.1 & 1 & 9.66 & 1.78 & 17.17 & 2.25 & 8.99 & 2.08 & 8.34 & 0.90 & 3.60 \\
\hline & Z15 & 5.7 & 2.7 & 1.5 & 23.09 & 1.75 & 40.44 & 3.32 & 13.27 & 3.02 & 12.10 & 1.14 & 4.56 \\
\hline
\end{tabular}

sampled from boulder Qa2 has been dated back to post 1954 (Table 4), confirming a storm origin.

On the Qawra peninsula, the coast is gentle sloping and tens of boulders are distributed at an average elevation of 1 or $3 \mathrm{~m}$ (Fig. 4c). Their lithology consists of Lower Coralline Limestone. Their distance from the coastline can reach up to $50 \mathrm{~m}$ and overall, the deposits are imbricated towards north.

One radiocarbon dating test was performed on a serpulid polychaete, sampled from the most distant and representative boulder (Table 4). This boulder also had cemented serpulid tubes, a skeleton of coral polyp (likely Caryophyllia sp.) and several bores made by lithophage bivalves (such as the date mussel Lithophaga lithophaga) with no shells visible in the holes. On the other hand, there were no vermetid concretions. Taken together, these observations strongly suggest that the sampled boulder was originally fully submerged, in a joint bounded submerged scenario.

The results obtained by the hydrodynamic equations of Nandasena et al. (2011) and Pignatelli et al. (2009) (Table 3) show that three out of four sampled boulders require waves that exceed $7.1 \mathrm{~m}$. On the contrary, according to Engel and May's (2012) equation, the values are lower (1.7-2.7 m). Among these boulders, the serpulid sampled from boulder Qa1 has been dated back to post 1954 (Table 4). Given that only one accelerator mass spectrometry (AMS) age was obtained from these sampled boulders, their original position

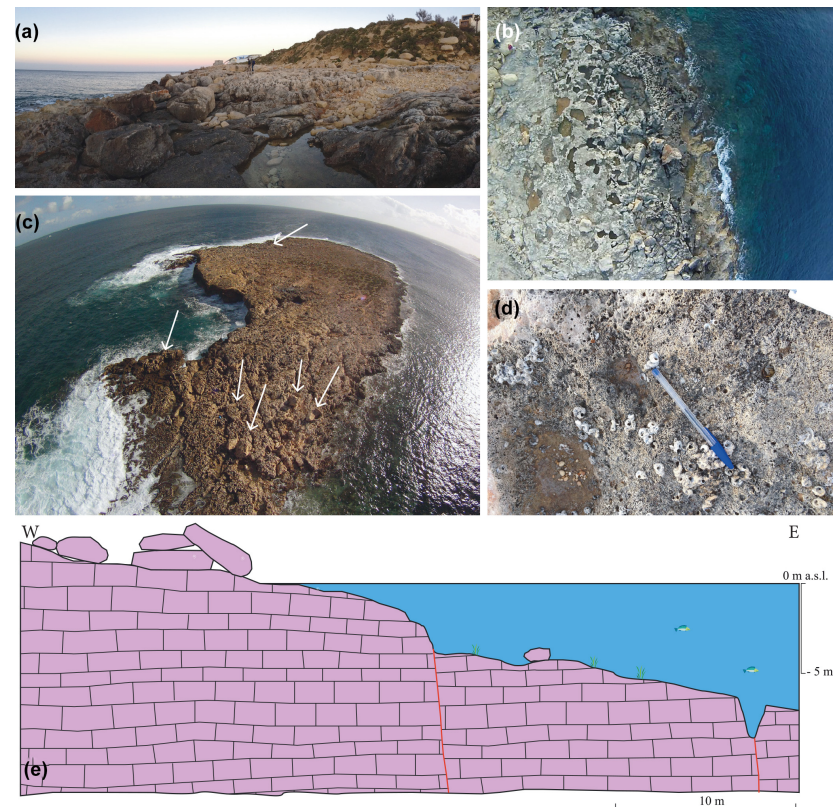

Figure 4. (a) Boulder deposit at Bugibba; (b) view of the deposit from UAV; (c) view of Qawra peninsula from UAV; (d) vermetid shells; (e) reconstruction of the submerged environment. 
Table 4. Accelerator mass spectrometry (AMS) ${ }^{14} \mathrm{C}$ dating of marine organisms performed by the CeDaD Laboratory (Centro di Datazione e Diagnostica) of the University of Salento, Brindisi, Italy. The last column lists the historical tsunamis which occurred in the Mediterranean Sea in the ranges of the radiocarbon ages (Tinti et al., 2004; Papadopoulos et al., 2014). pCM denotes percent of modern carbon.

\begin{tabular}{|c|c|c|c|c|c|c|}
\hline $\begin{array}{l}\text { Boulder } \\
\text { (site) }\end{array}$ & $\begin{array}{l}\text { Calibration } \\
\text { method }\end{array}$ & $\begin{array}{l}\text { Type of } \\
\text { organism }\end{array}$ & $\begin{array}{l}\text { Radiocarbon } \\
\text { age }(\mathrm{BP})\end{array}$ & $\begin{array}{r}\delta^{13} \mathrm{C} \\
(\% o)\end{array}$ & $\begin{array}{l}\text { Cal. age } \\
\text { (BC or } \mathrm{AD})\end{array}$ & $\begin{array}{l}\text { Historical } \\
\text { tsunamis }\end{array}$ \\
\hline AB1 (Armier Bay) & $1 \mathrm{MMNH}(+)$ & $\begin{array}{l}\text { Vermetidae } \\
\text { (D. petraeum) }\end{array}$ & $2784 \pm 45$ & $-2.2 \pm 0.4$ & $514 \pm 104 \mathrm{BC}$ & $\begin{array}{l}515 \text { BC } \\
\text { (Rhodes?) }\end{array}$ \\
\hline AB2A (Armier Bay) & 2 MMHM & $\begin{array}{l}\text { Vermetidae } \\
(\text { D. petraeum })\end{array}$ & $1095 \pm 45$ & $-3.4 \pm 0.2$ & $\mathrm{AD} 1298 \pm 46$ & $\begin{array}{l}1329 \text { (eastern } \\
\text { Sicily) }\end{array}$ \\
\hline AB4A (Armier Bay) & $5 \mathrm{MMHM}$ & Chthamalidae & $1525 \pm 45$ & $-0.5 \pm 0.5$ & $\mathrm{AD} 938 \pm 70$ & $\begin{array}{l}963 \text { (eastern } \\
\text { Sicily) }\end{array}$ \\
\hline AB6 (Armier Bay) & $6 \mathrm{MMHM}$ & $\begin{array}{l}\text { Vermetidae } \\
\text { (D. petraeum) }\end{array}$ & $1147 \pm 45$ & $-0.5 \pm 0.3$ & $\mathrm{AD} 1290 \pm 54$ & $\begin{array}{l}1329 \text { (eastern } \\
\text { Sicily) }\end{array}$ \\
\hline AB7 (Armier Bay) & 7 MMHM & $\begin{array}{l}\text { Vermetidae } \\
(\text { D. petraeum })\end{array}$ & $2229 \pm 45$ & $-4.5 \pm 0.8$ & $\mathrm{AD} 122 \pm 72$ & 148 (Rhodes)? \\
\hline C16 (Armier Bay) & - & $\begin{array}{l}\text { Vermetidae } \\
(T \text {. arenarius })\end{array}$ & $\begin{array}{l}107.08 \pm 0.60 \\
\mathrm{pMC}\end{array}$ & $-0.6 \pm 0.5$ & Post 1954 & \\
\hline Q2 (Armier Bay) & $\begin{array}{l}8 \\
\text { Marine13.14c }\end{array}$ & $\begin{array}{l}\text { Vermetidae } \\
\text { (V. triquetrus) }\end{array}$ & $1026 \pm 45$ & $+4.0 \pm 0.5$ & $\mathrm{AD} 1384 \pm 47$ & $\begin{array}{l}1329 \text { (eastern } \\
\text { Sicily) }\end{array}$ \\
\hline C82/AB5 (Armier Bay) & $\begin{array}{l}9 \\
\text { Marine13.14c }\end{array}$ & $\begin{array}{l}\text { Vermetidae } \\
(\text { D. petraeum })\end{array}$ & $1582 \pm 45$ & $7.4 \pm 0.6$ & $\mathrm{AD} 869 \pm 75$ & $\begin{array}{l}963 \text { (eastern } \\
\text { Sicily) }\end{array}$ \\
\hline Qa1 (Qawra) & - & Serpulidae & $\begin{array}{l}110.34 \pm 0.59 \\
\mathrm{pMC}\end{array}$ & $-6.3 \pm 0.3$ & Post 1954 & \\
\hline Qa2 (Buġibba) & - & $\begin{array}{l}\text { Vermetidae } \\
(\text { D. petraeum })\end{array}$ & $\begin{array}{l}108.52 \pm 0.55 \\
\mathrm{pMC}\end{array}$ & $-5.6 \pm 0.6$ & Post 1594 & \\
\hline B1 (Bahar ic̀-Ċaghaq) & 3 ММHМ & $\begin{array}{l}\text { Vermetidae } \\
(\text { D. petraeum })\end{array}$ & $278 \pm 45$ & $-2.2 \pm 0.6$ & $\mathrm{AD} 1672 \pm 45$ & $\begin{array}{l}1693 \text { (Sicily), or } \\
1743 \text { (Apulia) }\end{array}$ \\
\hline 16 (Pembroke) & 4 ММНМ & $\begin{array}{l}\text { Vermetidae } \\
(\text { D. petraeum })\end{array}$ & $227 \pm 40$ & $-3.7 \pm 0.5$ & $\mathrm{AD} 1723 \pm 40$ & $\begin{array}{l}1693 \text { (Sicily) or } \\
1743 \text { (Apulia) }\end{array}$ \\
\hline Z1 (Żonqor) & - & Vermetidae & $\begin{array}{l}108.92 \pm 0.53 \\
\mathrm{pMC}\end{array}$ & $-6.1 \pm 0.4$ & Post 1954 & \\
\hline
\end{tabular}

may be questionable and needs to be validated with more dating.

\subsection{Bahar ić-Ċaghaq}

Bahar ic-Caghaq is located on the central part of the eastern coast, between Qawra and Pembroke (Fig. 2). The wind and wave conditions that prevail in the Qawra-Bugibba area are also present here. Relatively shallow waters in close proximity to the coastline create high-energy areas with irregular and violent conditions.

Along the coast where the Splash and Fun Water Park is located, a wide flat platform occurs and is composed of the highest unit of the Lower Coralline Limestone.
The platform is covered by tens of metric boulders (Fig. 5a and $b$ ), which are imbricated toward NE.

Tens of boulders and several sections of the coast exhibit fresh detachment surfaces and indented contours. Impact marks due to the dragging of boulders on the platform are also still visible, suggesting recent movements. As seen in Table 3, the results of the hydrodynamic equations provided values comparable with storm waves.

Some of these boulders had dense clusters of Vermetidae (mainly D. petraeum) tubes cemented together on the surface, and with spaces infilled by the calcareous Rhodophyta Neogoniolithon brassica-florida, together with remnants of other biota (e.g. the bivalves Cardita calyculata and Chama gryphoides) that are commonly associated with vermetid aggregations. These vermetid crusts are typical of the midlittoral to infralittoral transition, indicating that the surface of 

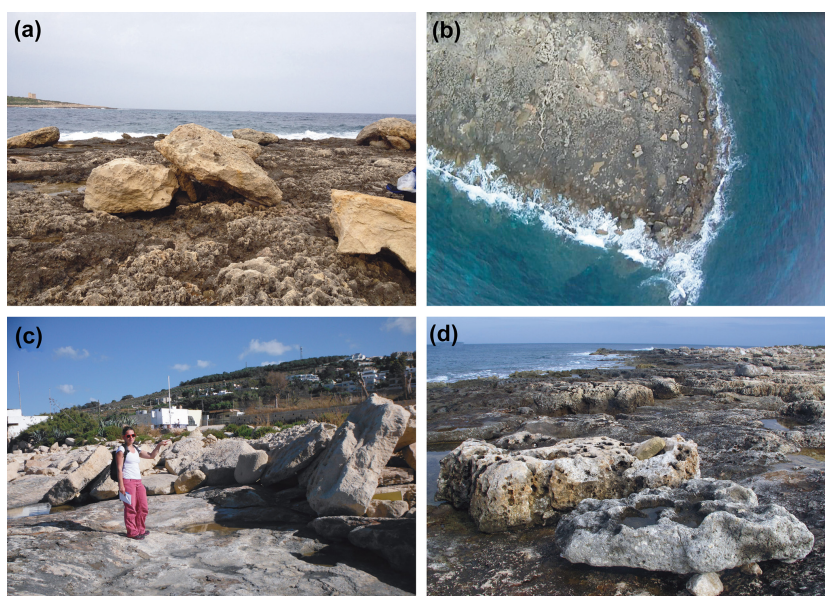

Figure 5. Splash and Fun Water Park: (a) scattered boulders belonging to LCL; (b) UAV view of the deposit; (c) Bahar ić-Cagharaq: boulders belonging to GLO; (d) isolated boulders at Pembroke (the underwater profiles are very similar to Fig. 4e).

these boulders was originally at approximately mean sea level. One of these boulders also contained bores made by the bivalve Lithophaga lithophaga, an upper infralittoral species. Also in this case, we propose a joint bounded submerged scenario.

Moving towards south, the lithology of the coast, as well as that of boulders, changes into Globigerina Limestone formation. The boulder deposits extend for about $700 \mathrm{~m}$ and consist of hundreds of blocks, all metric in size, which have been deposited up to $30 \mathrm{~m}$ away from the coastline (Fig. 5c) and are imbricated mainly toward NE.

At sea level, a $2 \mathrm{~m}$ high scarp is present and is connected to a wide low-lying platform, with an average slope of $5^{\circ}$. The bedding is gently inclined toward the sea and its thickness is of about $0.5 \mathrm{~m}$. The scarp contour is indented and fresh detachment surfaces and fractures are clearly visible. The boulders are all scattered on the low-lying platform, where the bedding favoured the fracturing and the detachment of rock masses. Some of them are covered by marine encrustations, often very recent. These bioforms are similar to those observed on the LCL boulders slightly further north, and include vermetid crusts and associated biota. One specific small-sized boulder contained numerous bores with Lithophaga lithophaga, as well as serpulid and spirorbid polychaete tubes, the coralline alga Ellisolandia elongata and remains of the green alga Cystoseira amentacea, indicating that the boulder originated from the upper infralittoral region (joint bounded submerged scenario). Given that green algae are not encrusting species and rapidly erode away, this specific boulder must have been transported out of the water during a very recent storm event.

The application of the hydrodynamic equations (Table 3 ) was tested on 14 sampled boulders, and only one result required a wave higher than $8 \mathrm{~m}$ according to Nandasena et al. (2011) and Pignatelli et al. (2009), while for Engel and May (2012), the result is completely different: $4.17 \mathrm{~m}$. In any case the values are comparable with the Maltese wave regime. The dated vermetid crust on boulder B1, AD $1672 \pm 45$ (Table 4), may be linked to two different historical tsunami events which occurred in the vicinity of eastern Sicily: 1693 and 1743. However, the storm wave height obtained by the hydrodynamic equations for this boulder was lower than $5 \mathrm{~m}$. Even here, such a result is inconclusive, given that only one AMS age was calculated.

\subsection{Pembroke}

The surveyed area is located along the eastern coast of Malta, a few hundred metres east of the coastal town of Pembroke. The same conditions of winds and waves which prevail in the Qawra-Bugibba area are also present here. Relatively shallow waters in close proximity to the coastline create highenergy areas with irregular and violent conditions.

From a geomorphological point of view, the outcrop consists of a low-lying rocky area of Lower Coralline Limestone formation.

Numerous boulders, most of which are imbricated toward NNE, have been measured and described. Generally they show a roughly rectangular shape, sometimes more rounded, with a more or less evident planar side corresponding to the detachment surface. The boulders are from decimetric to metric in dimension and are characterised by a longer axis on average from $1 \mathrm{~m}$, up to maximum values of $2.5 \mathrm{~m}$ and an overall thickness of less than $1 \mathrm{~m}$ (Fig. $5 \mathrm{~d}$ ).

Most of the boulders identified in the Pembroke area are located more than $20 \mathrm{~m}$ inland and are partly covered by a vermetid crust made by $D$. petraeum and the coralline alga Neogoniolithon brassica-florida. These crusts occur at the transition between the lower midlittoral and upper infralittoral transition, and therefore represent the evidence of at least one submarine phase of these rocks with their upper surface located at approximately mean sea level (i.e. joint bounded submerged scenario). The absence of similar encrustations on the fracture planes of the boulders suggests that these originally formed part of the rocky coastline extending into the sea, and were subsequently detached and transported to their present position on land.

With regards to the hydrodynamic equations (Table 3), for the 10 measured boulders, the results show that only one of them required waves higher than $10.2 \mathrm{~m}$ to be detached from the coastal edge according to Nandasena et al. (2011) and Pignatelli et al. (2009). However, according to Engel and May (2012), all values are lower, between 2.6 and $5.7 \mathrm{~m}$. The dated organism from boulder P16 provided an age of AD $1723 \pm 40$, but the hydrodynamic calculations seem to indicate more the likelihood of detachment by ordinary storm waves. 


\section{5 Żonqor}

Żonqor is the southernmost location on the NE-facing coast of the sites investigated in this study. The area takes the shape of a headland formed by the open coast to the left and the entrance to Marsascala Bay to the right. It consists of a gently sloping rock coast where the slope is mainly controlled by the dip of the bedding strata. The tip of the headland extends below sea level for some $500 \mathrm{~m}$ in an ESE direction up to a depth of $-10 \mathrm{~m}$, forming a long and narrow reef. The variation in water depth in the reef area causes considerable wave refraction around the headland, whilst its aspects render it susceptible to impact by waves approaching from a range of directions between the $\mathrm{N}$ and the SE.

The local bedrock is composed of Lower Globigerina Limestone and Lower Coralline Limestone. In this area the contact between these two layers is marked by a phosphatic nodule conglomerate bed. The exposed Globigerina is generally smooth in appearance and thickly bedded; however on the headland it is highly weathered, exhibiting a number of fissures and fractures which have been filled and hardened with a red-brown caliche crust.

The Lower Coralline Limestone layer is exposed in some tracts, where the Globigerina layer above has been stripped off along lines of discontinuity in the bedrock.

The Żonqor area is marked by a high quantity of boulders, many of which are angular and cuboidal in form (Fig. 6a). Their shape and size are determined by the joint patterns within the rock body from where they originate and range from less than $1 \mathrm{~m}$ to more than $8 \mathrm{~m}$ in length. Their average thickness varies between 40 and $80 \mathrm{~cm}$ depending on location and lithology. On the headland, the boulders form a number of distinct clusters and ridges. The two largest ridges measure 24 and $20 \mathrm{~m}$ in length and are aligned WNW-ESE (Fig. 6b). The majority of boulders in these ridges are either imbricated or aligned ( $a$ axis) towards the NE (Fig. 6c). Other smaller ridges and clusters show a prevalence of boulders imbricated or oriented towards the E, the ESE and the SE, corresponding to the aspect of the headland in relation to their position. These boulder accumulations are found approximately between 40 and $85 \mathrm{~m}$ from the shoreline.

Moving alongshore towards the NW, the boulder distribution changes. A fault trending WNW-ESE has created a depression up to $6 \mathrm{~m}$ wide in which several tens of boulders have been entrapped about $30 \mathrm{~m}$ from the shoreline. Some isolated boulders or clusters composed of a few clasts were observed landward of this fault. Further towards the NW, the coast is dotted with more boulder clusters, the majority of which show a NE imbrication or orientation. On the landward edge of the platform, a number of boulders form a berm that merges with a vegetated soft sediment slope, originating mainly from anthropogenic infill. This is located approximately $50 \mathrm{~m}$ inland.

The origin of the clasts at Żonqor seems to be principally from the supralittoral zone as evidenced from the number of
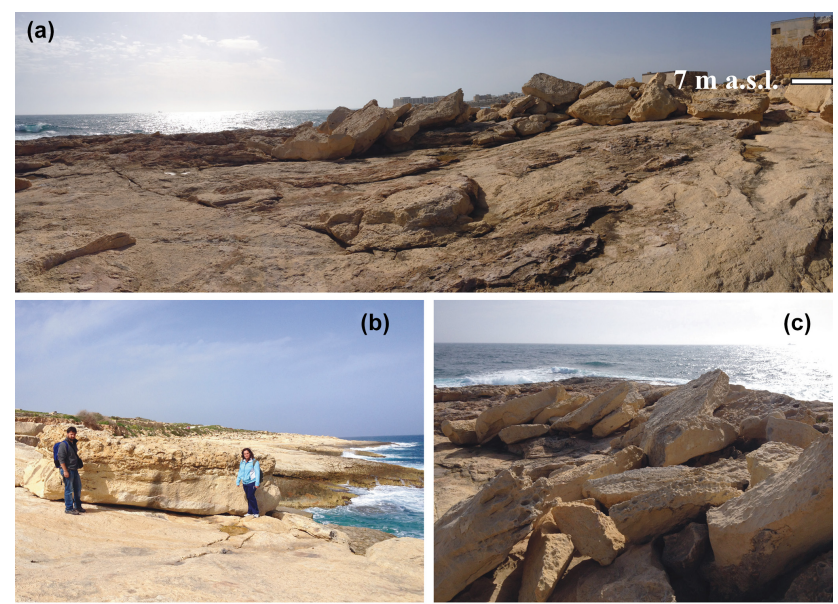

(b)

(c)

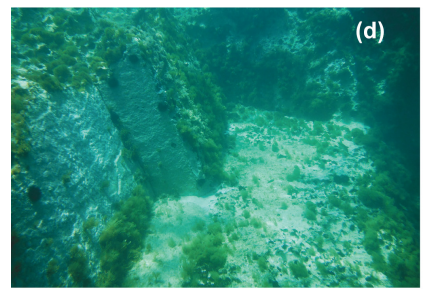

(d)
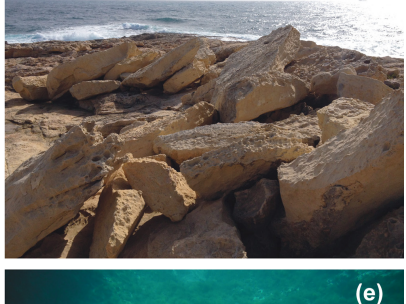

(f)

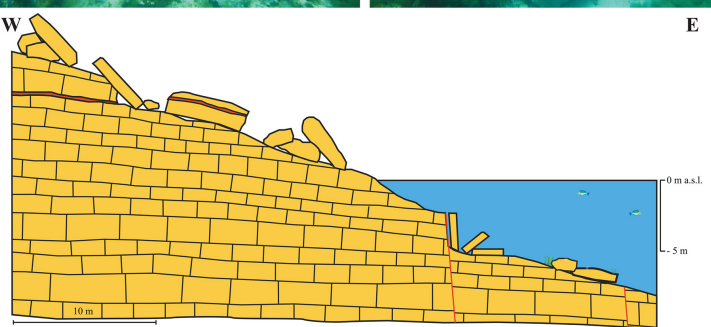

Figure 6. Żonqor: (a, b, c) boulder deposits; (d) underwater fresh detachment surfaces along bedding and fracture planes; (e) submerged rectangular and rounded metric boulders; (f) reconstruction of the submerged environment.

detachment scarps and exposed joint facies in the backshore. However a small number of boulders with encrusting algae and a variety of other marine organisms (including the vermetid molluscs $D$. petraeum and $T$. arenarius, bivalves such as $C$. calyculata and C. gryphoides and the lithophage Petricola lithophaga and several serpulid polychaetes) indicate a sublittoral origin.

Storm wave impact on this site is considerable, especially when the wave approach is from a NE direction and wave inundation can reach several metres inland. This can be inferred from observed boulder movement following storms during which wind speeds exceeded $45 \mathrm{~km} / \mathrm{h}$. One such boulder measuring $2.4 \mathrm{~m} \times 1.3 \mathrm{~m} \times 0.6 \mathrm{~m}$ was detached from the sublittoral zone and carried $15 \mathrm{~m}$ from the shoreline. The same boulder was moved a further $10 \mathrm{~m}$ inland and split into two parts, and the smaller part was transported once again some $14 \mathrm{~m}$ inland during subsequent storms.

According to the results obtained from the hydrodynamic equations (Table 3), within the 15 measured blocks, 6 of 
them required waves higher than $8.4 \mathrm{~m}$ to be detached from the coastal edge or from the sea bottom. The boulder $\mathrm{Z} 1$ provided a ${ }^{14} \mathrm{C}$ dating of post $\mathrm{AD} 1954$ (Table 4) and may have been affected by a storm wave of $3.94 \mathrm{~m}$ according to Pignatelli et al. (2009), $4.32 \mathrm{~m}$ according to Nandasena et al. (2011) or $2.51 \mathrm{~m}$ according to Engel and May's (2012) approach.

\section{Discussion}

From a morphological point of view, the occurrence of lowlying rocky coasts makes the eastern coast of Malta better predisposed to the accumulation of large boulder deposits derived from the impact of extreme waves. Moreover, the horizontal bedding, the presence of subvertical discontinuities and the poor geo-mechanical properties of the rocks play a crucial role in the rupture and detachment of large blocks from the coastline.

Concerning the pre-dislodgement setting of the boulders, a joint bounded submerged scenario is the most frequent, while for the boulders at Ahrax Point and locally at Żonqor, Bugibba and Bahar ić-Caghaq, a subaerial scenario is suggested. These settings were validated by underwater surveys carried out in all the investigated sites; in all locations, the shapes of the boulders correspond to the shapes of the pluck holes and detachment scarps. Originally, most of the large boulders investigated in this study must have been part of the coastline edge, since they comprise rock pools from the most seaward surface, as well as vermetid colonies.

Furthermore, according to local eyewitness accounts, several boulders recently deposited by swell waves were dislodged, moved and transported landward. Mechanical quarrying of the boulders requires the presence of initial cracks. As a matter of fact, most of the measured boulder $c$ and $b$ axes correspond respectively to bed thickness and bed planes, which are smooth at the base and karstified at the top. These discontinuities favoured the detachment of regular slabs. Especially at Żonqor, the quarrying of regularly shaped boulders is encouraged by the presence of subvertical faults and fractures, which are clearly visible also underwater.

On the other hand, at Ahrax Point, the boulders seem to have been detached from the top part of the cliff face, as they have not been colonised by marine organisms and the geomorphological setting includes a steep cliff very close to the deposits. These boulders are referred to as cliff-top storm deposits.

The application of the hydrodynamic equations (Table 3) has highlighted the lack of correlation between density and volume values and the obtained results, meaning larger boulders do not necessarily require higher waves to be detached from the coastline edge. When comparing results, it can be observed that the results of Nandasena et al. (2011) and Pignatelli et al. (2009) are very similar: the highest values ob- tained reach 14 and $13.35 \mathrm{~m}$ for the equations of Nandasena and 12.8 and $12.7 \mathrm{~m}$ for Pignatelli, thus recording a marginal difference of slightly more than $1 \mathrm{~m}$. For all the other values, the decrease of the storm wave height values also decreases the difference between the obtained results. Out of the 77 selected boulders, 22 boulders recorded storm wave heights exceeding the estimated breaking wave heights. Conversely, the calculated tsunami wave heights are very low and range between $3.5 \mathrm{~m}$ ( 3.2 for Pignatelli) and $0.55 \mathrm{~m}$ ( 0.51 for Pignatelli). Engel and May's (2012) equations obtained values much lower relatively, with the storm wave heights ranging from 0.9 to $6.5 \mathrm{~m}$ and tsunami wave height from 0.2 to $1.6 \mathrm{~m}$.

Equally, the obtained values for tsunami wave heights are comparable to those observed during the 1908 earthquake (Pino et al., 2008; Guidoboni and Mariotti, 2008), as well with those obtained by Tinti et al. (2005) for tsunamis generated by earthquakes both in eastern Sicily and in the Western Hellenic Arc.

In comparing their results, these equations provide values which are too different from each other, even though they take into account different parameters and sometimes consider scenarios which are distant from the real geomorphological setting. It was noticed that bulk and volume values do not influence the results in the same way when using different equations. Moreover, parameters such as the distance from the coastline, the elevation position of a boulder and the local topographical characteristics of the sea bottom are not taken into consideration. These are the reasons why it can be concluded that the hydrodynamic approach as a standalone method is not sufficient to distinguish between storm and tsunami waves.

With regards to the position of the boulders, we are not able to establish whether the current position of the boulders is the original one when the first depositional event occurred. There is the possibility that some boulders may have been deposited on the coast by a tsunami event and later transported and deposited by storm waves to their present position. As a matter of fact, comparing the distance from the coastline with the mass of each boulder for each site (Fig. 7), two different distributions can be observed (the Ahrax Point case is not representative because of the poor number of data).

At Armier Bay and Żonqor, the distribution is regular, with the lighter boulders as the ones further way from the coastline. This could be indicative of a storm event or of a "perfect tsunami", but the radiocarbon dating results on different boulders at Armier Bay are varied. In this case, even if the diagram in Fig. 7 is typical of a storm, we suggest the combined action of storms (which may occasionally be severe) and one or more tsunamis. For the Żonqor site, the hypothesis of extreme storms is confirmed by the hydrodynamic approach as well as by radiocarbon dating and the geomorphological and biological characteristics.

At Bahar ić-Caghaq, Bugibba and Pembroke, the boulders are scattered and their distribution is highly irregular, indicating a chaotic event or the succession of several events. 

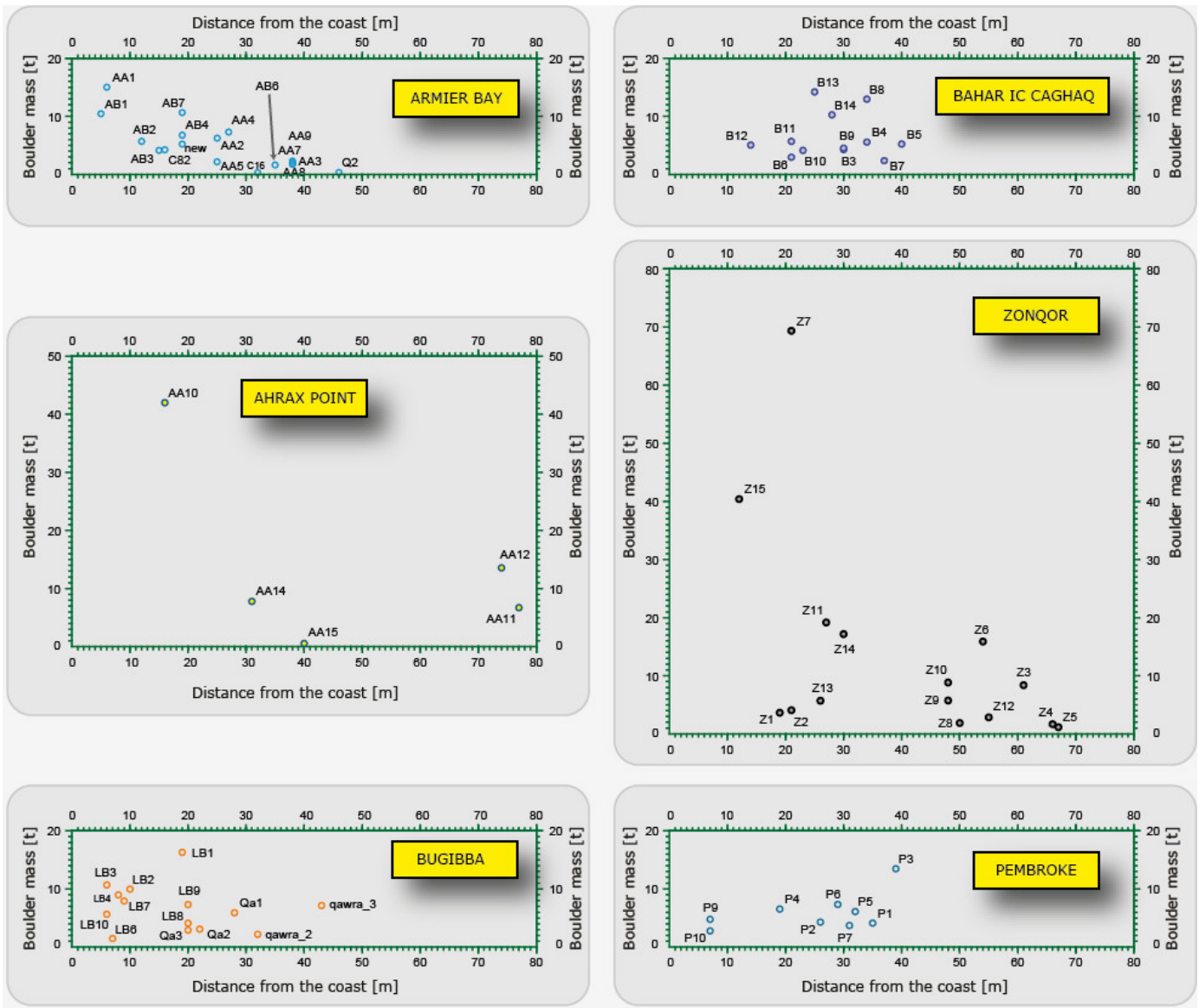

Figure 7. Relationship between the distance from the coast $(x)$ and the boulder mass $(y)$.

However, such a distribution of the boulders and their dating (post 1954 for Bugibba, AD $1672 \pm 45$ for Bahar ićCaghaq and $\mathrm{AD} 1723 \pm 40$ for Pembroke) may indicate the succession of several events (storm and storms, or storm and tsunami or tsunami and tsunami).

Radiocarbon dating was performed on marine organisms sampled from 10 representative boulders in all the sites. Moreover, three dating samples provided by Biolchi et al. (2016) were recalibrated (Table 4; Fig. 8). Four samples support the hypothesis of recent strong storm events, dating back to post AD 1954. This occurred in particular at Żonqor Point, which is exposed to storms blowing from more than one direction. The north-easterly storms batter this stretch of coastline just as they do in areas such as Qawra. However, Żonqor Point is also exposed to storms that originate from the south-east - known locally as "Xlokk". Such storms can blow both in winter and in summer, and their strength, though not as powerful as storms from the north-east, can create very rough conditions in the area.

Additional proof of recent extreme waves is provided by tracks on freshly damaged karst surfaces, generated by rolling/saltating boulder transport, which lead directly from the fresh scarp at the terrace edge to the boulder's current position.

Other radiocarbon dating seems to be related to events (extreme storms and/or tsunamis) occurring in a time span ranging from $514 \pm 104 \mathrm{BC}$ to $\mathrm{AD} 1723 \pm 40$. They have been compared with historical events (Papadopoulos et al., 2014; Tinti et al., 2004). Our results could be tentatively linked to some of these tsunami events which have occurred in the Mediterranean Sea and the Aegean Sea (Table 4). Amongst them, the most ancient are the $373 \mathrm{BC}$ (west Corinthian Gulf) and the $426 \mathrm{BC}$ (island of Crete) events for the boulder AB1 at Armier Bay; but this boulder, despite its significant size $(4.2 \times 2.8 \times 0.5 \mathrm{~m})$, is located very close to the the coast $(15 \mathrm{~m})$ and is placed above other boulders.

The event of AD 963, which occurred in eastern Sicily, which is reported in the tsunami catalogue provided by Tinti et al. (2004) as a "false event", could instead be tentatively proven by two nearby boulders at Armier Bay (AB4 and C82). The more recent event of AD 1303 (Crete Island) and, more probably, the AD 1329 (eastern Sicily) event, could be related to three nearby boulders at Armier Bay (AB2, AB6 and Q2). Finally, two other events, which occurred in the early modern period and have been reported in histor- 


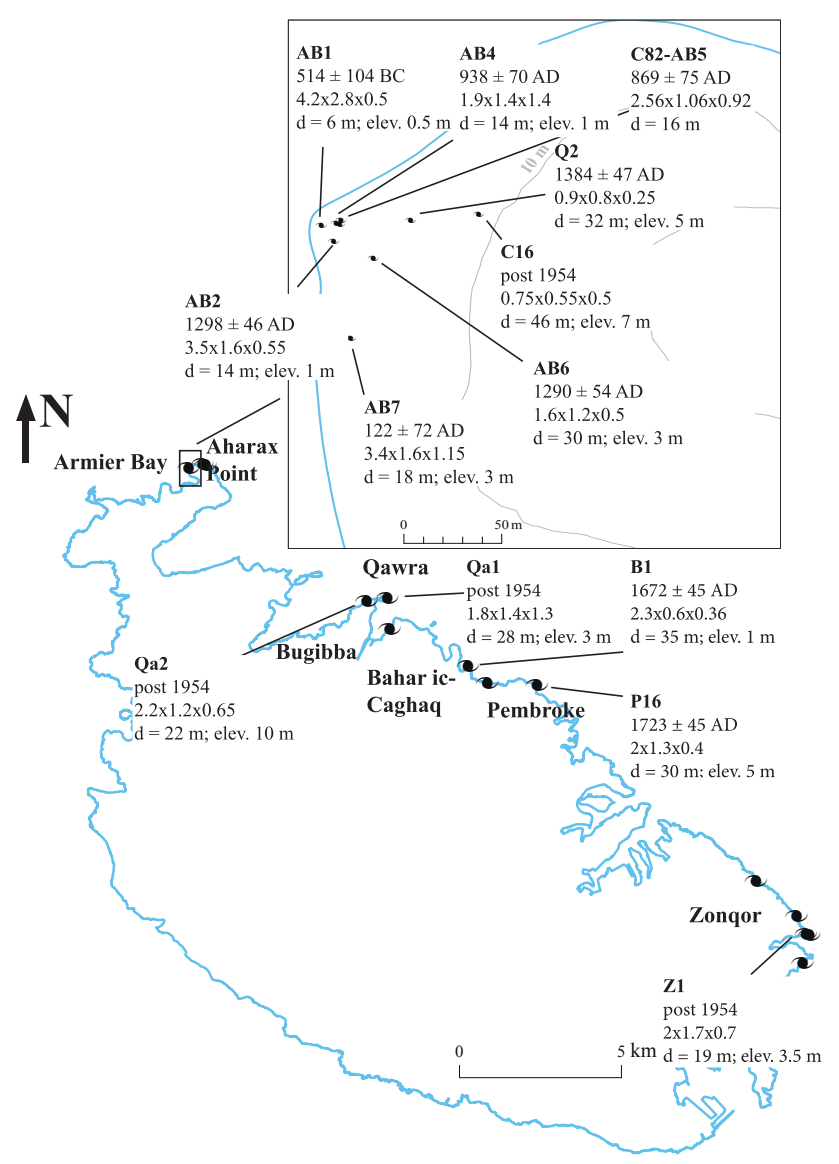

Figure 8. Location of the investigated boulders, with a zoom of the Armier Bay Ahrax Point site, with their AMS dating, size, distance from the coastline and elevation above sea level.

ical accounts of Malta (De Soldanis, 1746; Galea, 2007) are the AD 1693 (eastern Sicily) and the AD 1743 (Apulia, Lower Ionian Sea) events. These strong earthquakes triggered tsunamis which, according to Scicchitano et al. (2007) and Mastronuzzi et al. (2007), are responsible for similar boulder deposits in eastern Sicily and the Apulia region. These two tsunamis could be related to the boulders located at Bahar ić-Caghaq (B1) and Pembroke (16). Gozitan historian Agius de Soldanis writes the following description of the 1693 event in his 1746 account. "On 11 January of this year, the earth trembled and everyone was scared. The earthquake damaged the Collegiate Church and many other churches. The sea at Xlendi receded instantly and returned back with great fury like a tidal wave and with a thundering sound. At Sannat a part of the land measuring round a wejba crumbled down into the sea" (De Soldanis, 1746, p. 149).

Unfortunately, these claims could not be further verified since

a. the radiocarbon age is limited due to the limited number of samples and to the calibration; b. the hydrodynamic approach does not seem to confirm the hypothesis of ancient tsunamis, as the estimated values for storm wave heights are acceptable for the Maltese regime.

\section{Conclusions}

Along the eastern and north-eastern Maltese coasts, about 20 boulder deposits occurred. Reconstructing the history of these blocks and distinguishing events, such as storm waves or tsunamis, play a crucial role in assessing this type of coastal geo-hazard. A detailed field survey has been carried out along the Maltese coasts in order to identify and map all the sites in which these kinds of deposits occur, to analyse their characteristics in detail, to determine their provenance and study the processes responsible for their transport from the sea to the coast.

Data suggest that these boulders testify to the existence of a real hazard for the eastern and north-eastern coasts, considering the high land use development and coastal infrastructures present in proximity to the Maltese coastline on this part of the island. The frequent storms affecting the Maltese coasts are able to detach large boulders both from the coast edge and the sea bottom, and to transport them onshore. Very high waves are common. They can detach and move blocks whose volume can exceed $10 \mathrm{~m}^{3}$. These blocks can be detached and moved inshore, or boulders can be initially overwhelmed and brought inshore only at a later time. The occurrence of recent extreme storm waves is supported by radiocarbon dating performed on marine organisms. Such events are likely to increase in frequency and intensity due to climate change, whilst sea level rise, even of a temporary nature, such as that brought about by a storm surge, could shift coastal processes landward and impinge on urban areas.

However, the possibility that one or more tsunami events may have affected these coasts cannot be ruled out, since radiocarbon dating of some marine organisms encrusted on the boulders surfaces has revealed ages that can be related to historical known tsunamis. In particular, at the Armier Bay site (north-eastern coast), there could be geomorphological evidence of the AD 963 and 1329 tsunami events, which occurred in eastern Sicily (southern Italy). Conversely, at Bahar ić-Caghaq and Pembroke (eastern coast), two boulders could be related to one of the two most important tsunamis (AD 1693, eastern Sicily, or AD 1743, Apulia), which have also been reported in the historical accounts of Malta.

Thus a national risk assessment of extreme wave events will need to consider both an ongoing monitoring system of storm wave events and related impacts on the low-lying urban coasts, as well as the inclusion of the Maltese islands in a Mediterranean-based tsunami early warning system, as part of a long-term strategic hazard management plan. 
Acknowledgements. This work has been partially funded by the SIMIT Project "Integrated Civil Protection System for the ItaloMaltese Cross-Border Area" (Italia-Malta Programme - Cohesion Policy), the Research Project COFIN MIUR 2010-2011 "Response of morphoclimatic system dynamics to global changes and related geomorphological hazard" and by the Flagship Project RITMARE - The Italian Research for the Sea - coordinated by the Italian National Research Council and funded by the Italian Ministry of Education, University and Research within the National Research Program 2011-2013.

The paper is an Italian contribution to IGCP project no. 588 - International Geological Correlation Programme by UNESCO-IUGS.

Finally, the authors are grateful to the Falck family for the partial funding of research activities.

The authors wish to thank the editor S. Tinti and the two anonymus reviewers for useful suggestions and corrections that significantly contributed to the improvement of the paper.

Edited by: S. Tinti

Reviewed by: two anonymous referees

\section{References}

Alexander, D.: A review of the physical geography of Malta and its significance for tectonic geomorphology, Quaternary Sci. Rev., 7, 41-53, 1988

Argnani, A. and Bonazzi, C.: Malta Escarpment fault zone offshore eastern Sicily: Pliocene-Quaternary tectonic evolution based on new multichannel seismic data, Tectonics, 24, 1-12, 2005.

Aydin, A. and Basu, A.: The Schmidt hammer in rock material characterization, Eng. Geol., 81, 1-14, 2005.

Azzaro, R. and Barbano, M. S.: Analysis of seismicity of Southeastern Sicily: proposal of a tectonic interpretation, Ann. Geofis., 43, 171-188, 2000

Baldassini, N. and Di Stefano, A.: New insights on the OligoMiocene succession bearing phosphatic layers of the Maltese Archipelago, Ital. J. Geosci., 134, 355-366, 2015.

Baldassini, N., Mazzei, R., Foresi, L. M., Riforgiato, F., and Salvatorini, G.: Calcareous plankton bio-chronostratigraphy of the Maltese Lower Globigerina Limestone member, Acta Geol. Pol., 63, 105-135, 2013

Baratta, M.: I terremoti d'Italia; saggio di storia geografia e bibliografia sismica italiana. Torino, [ristampa anastatica, A. Forni Ed., Sala Bolognese, 1980], 950 pp., 1901.

Barbano, M. S., Pirrotta, C., and Gerardi, F.: Large boulders along the South-eastern Ionian coast of Sicily: storm or tsunami deposits?, Mar. Geol., 275, 140-154, 2010.

Bertolaso, G., Boschi, E., Guidoboni, E., Valensise, G. (a cura di): Il terremoto e il maremoto del 28 dicembre 1908: analisi sismologica, impatto prospettive, INGV-DPC, Roma, Bologna, 813 pp., 2008.

Bianca, M., Monaco, C., Tortorici, L., and Cernobori, L.: Quaternary normal faulting in Southeastern Sicily (Italy): a seismic source for the 1693 large earthquake, Geophys. J. Int., 139, 370394, 1999.

Biolchi, S., Furlani, S., Devoto, S., Gauci, R., Castaldini, D., and Soldati, M.: Geomorphological identification, classification and spatial distribution of coastal landforms of Malta (Mediterranean Sea), J. Maps, 12, 87-99, 2016

Boschi, E., Ferrari, G., Gasperini, P., Guidoboni, E., Smriglio, G., and Valensise, G.: Catalogo dei forti terremoti in Italia dal 461 a.C. al 1980, Istituto Nazionale di Geofisica, S. G. A., Roma, 1995.

Brandano, M., Frezza, V., Tomassetti, L., Pedley, M., and Matteucci, R.: Facies analysis and palaeoenvironmental interpretation of the Late Oligocene Attard Member (Lower Coralline Limestone Formation), Malta, Sedimentology, 56, 1138-1158, 2009.

Catalano, S., De Guidi, G., Lanzafame, G., Monaco, C., and Tortorici, L.: Late Quaternary deformation on the island of Pantelleria: New constraints for the recent tectonic evolution of the Sicily Channel Rift (Southern Italy), J. Geodyn., 48, 75-82, 2009.

Causon Deguara, J. and Gauci R.: Boulder and megaclast deposits on the South-east coast of Malta: signature of storm or tsunami event?, in: Proceedings Fifth International Symposium Monitoring on Mediterranean Coastal Areas: Problems and Measurement Techniques, Livorno (Italy) 17-18-19 June 2014, edited by: Benincasa, F., published by CNR-IBIMET, Florence, Italy, 594-603, 2014.

Causon Deguara, J.: A Study of Shore Deposits on the Coastline between Xghajra and Żonqor - Marsascala, Unpublished Masters of Arts dissertation, Department of Geography, University of Malta, Malta, 2015.

Civile, D., Lodolo, E., Tortorici, L., Lanzafame, G., and Brancolini, G.: Relationships between magmatism and tectonics in a continental rift: The Pantelleria Island region (Sicily Channel, Italy), Mar. Geol., 251, 32-46, 2008.

Corti, G., Cuffaro, M., Doglioni, C., Innocenti, F., and Manetti, P. Coexisting geodynamic processes in the Sicily Channel, Geol. S Am. S., 409, 83-96, 2006.

Cultrera, F., Barreca, G., Scarfì, L., Monaco, C.: Fault reactivation by stress pattern reorganization in the Hyblean foreland domain of SE Sicily (Italy) and seismotectonic implications, Tectonophysics, 661, 215-228, 2015.

De Soldanis, G. P.: Il Gozo Antico-moderno e Sacroprofano, Isola Mediterranea adiacente a Malta Africana. Gozo, Malta (Gozo, Ancient and Modern Religious and Profane), in: Manuscript National Archives, edited by: Mercieca, A., Media Centre Publications, Malta, 1746.

Devoto, S., Biolchi, S., Bruschi, V. M., Furlani, S., Mantovani, M., Piacentini, D., Pasuto, A., and Soldati, M.: Geomorphological map of the NW coast of the Island of Malta, J. Maps, 8, 33-40, 2012.

Devoto, S., Biolchi, S., Bruschi, V. M., González-Díez, A., Mantovani, M., Pasuto, A., Piacentini, D., Schembri, J. A., and Soldati, M.: Landslides along the North-West coast of the Island of Malta, in: Landslide Science and Practice, Vol. 1: Landslide Inventory and Susceptibility and Hazard Zoning, edited by: Margottini, C., Canuti, P., and Sassa, K., Springer, Heidelberg, 57-64, 2013.

Drago, A., Azzopardi, J., Gauci, A., Tarasova, R., and Bruschi, A.: Assessing the offshore wave energy potential for the Maltese Islands, Sustainable Energy 2013: the ISE annual conference, Malta, 2013.

Emanuel, K. A.: Increasing destructiveness of tropical cyclones over the past 30 years, Nature, 436, 686-688, 2005. 
Engel, M. and May, S. M.: Bonaire's boulder fields revisited: evidence for Holocene tsunami impact on the Leeward Antilles, Quaternary Sci. Rev., 54, 126-141, 2012.

Fago, P., Pignatelli, A., Piscitelli, A., Milella, M., Venerito, M., Sansò, P., and Mastronuzzi, G.: WebGIS for Italian tsunami: A useful tool for coastal planners, Mar. Geol., 35, 369-376, 2014.

Finetti, I. R.: Geophysical study of the Sicily Channel Rift Zone, Boll. Geof. Teor. Appl., 26, 3-28, 1984.

Fita, L., Romero, R., Luque, A., Emanuel, K., and Ramis, C.: Analysis of the environments of seven Mediterranean tropicallike storms using an axisymmetric, nonhydrostatic, cloud resolving model, Nat. Hazards Earth Syst. Sci., 7, 41-56, doi:10.5194/nhess-7-41-2007, 2007.

Furlani, S., Biolchi, S., Devoto, S., Saliba, D., and Scicchitano, G.: Large boulder along the NE Maltese coast: tsunami or storm wave deposits?, J. Coastal Res., 61, 470, 2011.

Galea, P.: Seismic history of the Maltese islands and considerations on seismic risk, Ann. Geophys.-Italy, 50, 725-740, 2007.

Giannelli, L. and Salvatorini, G.: I foraminiferi planctonici dei sedimenti terziari dell' Arcipelago maltese. II. Biostratigrafia di "Blue Clay", "Greensand" e "Upper Coralline Limestone", Atti Società Toscana di Scienze Naturali, Memorie, Serie A, 82, 124, 1975.

Goto, K., Chavanich, S. A., Imamura, F., Kunthasap, P., Matsui, T., Minoura, K., Sugawara, D., and Yanagisawa, H.: Distribution, origin and transport process of boulders deposited by the 2004 Indian Ocean tsunami at Pakarang Cape, Thailand, Sediment. Geol., 202, 821-837, 2007.

Goto, K., Okada, K., and Imamura, F.: Characteristics and hydrodynamics of boulders transported by storm waves at Kudaka Island, Japan, Mar. Geol., 262, 14-24, 2009.

Goto, K., Okada, K., and Imamura, F.: Numerical analysis of boulder transport by the 2004 Indian Ocean tsunami at Pakarang Cape, Thailand, Mar. Geol., 268, 97-105, 2010.

Grasso, M. and Pedley, H. M.: The Pelagian Island: A new geological interpretation from sedimentological and tectonic studies and its bearing on the evolution of the Central Mediterranean region (Pelagian Block), Geol. Romana, 24, 13-33, 1985.

Guidoboni, E., and Mariotti, D.: Il terremoto e il maremoto del 1908: effetti e parametri sismici, in: Il terremoto e il maremoto del 28 dicembre 1908: analisi sismologica, impatto prospettive, edited by: Bertolaso, G., Boschi, E., Guidoboni, E., and Valensise, G. (a cura di):INGV-DPC, Roma, Bologna, 813 pp., 2008.

Hall, A. M., Hansom, J. D., Williams, D. M., and Jarvis J.: Distribution, geomorphology and lithofacies of cliff-top storm deposits: Examples from the high-energy coasts of Scotland and Ireland, Mar. Geol., 232, 131-155, 2006.

Hansom, J. D., Barltrop, N. D. P., and Hall, A. M.: Modelling the processes of cliff-top erosion and deposition under extreme storm waves, Mar. Geol., 253, 36-50, 2008.

Hilgen, F. J., Abels, H. A., Iaccarino, S., Krijgsman, W., Raffi, I., Sprovieri, R., Turco, E., and Zachariasse, W. J.: The Global Stratotype Section and Point (GSSP) of the Serravallian Stage (Middle Miocene), Episodes, 32, 152-166, 2009.

Imamura, F., Goto, K., and Ohkubo, S.: A numerical model for the transport of a boulder by tsunami, J. Geophys. Res.-Oceans, 113, CO1008, doi:10.1029/2007JC004170, 2008.
ISRM: Suggested methods for determining hardness and abrasiveness of rocks, Int. J. Rock. Mech. Min. Sci., Geomech. Abstr., 15, 89-97, 1978.

Katz, O., Reches, Z., and Roegiers, J. C.: Evaluation of mechanical rock properties using a Schmidt Hammer, Int. J. Rock Mech. Min., 37, 723-728, 2000.

Lionello, P., Bhend, J., Buzzi, A., Della-Marta, P.M., Krichak, S., Jansa, A., Maheras, P., Sanna, A., Trigo, I.F., and Trigo, R.: Cyclones in the Mediterranean region: climatology and effects on the environment, in: Mediterranean Climate Variability, edited by: Lionello, P., Malanotte-Rizzoli, P., and Boscolo, R., Elsevier, Amsterdam, 324-372, 2006.

Makris, J., Nicolich, R., and Weigel, W.: A seismic study in the western Ionian sea, Ann. Geophys., 6, 665-678, 1986.

Malta Environment and Planning Authority: Detailed investigations and feasibility studies on land reclamation at two indicated search areas, Technical Report 1, Vol. 1, Malta, 2007.

Malta Maritime Authority: 2003, Malta significant wave height study, Main Report, Malta, 2003.

Mastronuzzi, G. and Pignatelli, C.: The boulders berm of Punta Saguerra (Taranto, Italy): a morphological imprint of 4th April, 1836 Rossano Calabro tsunami?, Earth Planets Space, 64, 829-842, 2012.

Mastronuzzi, G. and Sansò, P.: Boulders transport by catastrophic waves along the Ionian coast of Apulia (Southern Italy), Mar. Geol., 170, 93-103, 2000.

Mastronuzzi, G. and Sansò, P.: Large boulder accumulations by extreme waves along the Adriatic coast of Southern Apulia (Italy), Quatern. Int., 120, 173-184, 2004.

Mastronuzzi, G., Pignatelli, C., and Sansò, P.: Boulder fields: A valuable morphological indicator of palaeotsunami in the Mediterranean sea, Z. Geomorphol. Supp., 146, 173-194, 2006.

Mastronuzzi, G., Pignatelli, C., Sansò, P., and Selleri G.: Boulder accumulations produced by the 20th February, 1743 tsunami along the coast of Southeastern Salento (Apulia region, Italy), Mar. Geol., 242, 191-205, 2007.

Mastronuzzi, G., Brückner, H., De Martini, P. M., and Regnauld, H.: Tsunami: from the open sea to the coastal zone and beyond, in: Tsunami: From Fundamentals to Damage Mitigation, edited by: Mambretti, S., WIT Press, Southampton, 1-36, 2013a.

Mastronuzzi, G., Capolongo, D., Ferilli, S., Marsico, A., Milella, M., Pignatelli, C., Piscitelli, A., and Sansò P.: Tsunami maximum flooding assessment in GIS environment, in: Tsunami: From Fundamentals to Damage Mitigation, edited by: Mambretti, S., WIT Press, Southampton, 61-80, 2013b.

Mastronuzzi, G., Calcagnile, L., Pignatelli, C., Quarta, G., Stamatopoulos, L., and Venisti, N.: Late Holocene tsunamogenic coseismic uplift in Kerkira Island, Greece, Quatern. Int., 332, 4860, 2014.

Micallef, A., Foglini, F., Le Bas, T., Angeletti, L., Maselli, V., Pasuto, A., and Taviani, M.: The submerged paleolandscape of the Maltese Islands: Morphology, evolution and relation to Quaternary environmental change, Mar. Geol., 335, 129-147, 2013.

Monaco, C. and Tortorici, L.: Active faulting in the Calabrian arc and eastern Sicily, J. Geodyn., 29, 407-424, 2000.

Monaco, C., Tapponier, P., Tortorici, L., and Gillot, P. Y.: Late Quaternary slip rates on the Acireale-Piedimonte normal faults and tectonic origin of Mt. Etna (Sicily), Eart. Planet. Sc. Lett., 147, 125-139, 1997. 
Mottershead, D., Bray, M., Soar, P., and Farres, P. J.: Extreme waves events in the central Mediterranean: Geomorphic evidence of tsunami on the Maltese Islands, Z. Geomorphol., 58, 385-411, 2014.

Nandasena, N. A. K., Paris, R., and Tanaka, N.: Reassessment of hydrodynamic equations: Minimum flow velocity to initiate boulder transport by high energy events (storms, tsunamis), Mar. Geol., 281, 70-84, 2011.

Noormets, R, Crook, K. A. W., and Felton, E. A.: Sedimentology of rocky shorelines: 3. Hydrodynamics of megaclast emplacement and transport on a shore platform, Oahu, Hawaii, Sediment. Geol., 172, 41-65, 2004.

Nott, J. F.: Extremely high-energy wave deposits inside the Great Barrier Reef, Australia: Determining the cause-tsunami or tropical cyclone, Mar. Geol., 141, 193-207, 1997.

Nott, J. F.: Waves, coastal boulder deposits and the importance of the pre-transport setting, Earth Planet. Sc. Lett., 210, 269-276, 2003.

Oil Exploration Directorate: Geological Map of the Maltese Island, Sheet 1 - Malta - Scale $1: 25,000$, Office of the Prime Minister, Malta, 1993.

Palano, M., Ferranti, L., Monaco, C., Mattia, M., Aloisi, M., Bruno, V., Cannavò, F., and Siligato, G.: GPS velocity and strain fields in Sicily and Southern Calabria, Italy: Updated geodetic constraints on tectonic block interaction in the central Mediterranean, J. Geophys. Res.-Sol. Ea., 117, B07401, doi:10.1029/2012JB009254, 2012

Panzera, F., D'Amico, S., Lotteri, A., Galea, P., and Lombardo, G.: Seismic site response of unstable steep slope using noise measurements: the case study of Xemxija Bay area, Malta, Nat. Hazards Earth Syst. Sci., 12, 3421-3431, doi:10.5194/nhess-123421-2012, 2012.

Papadopoulos, G. A., Gràcia, E., Urgeles, R., Sallares, V., De Martini, P. M., Pantosti, D., González, M., Yalciner, A. C., Mascle, J., Sakellariou, D., Salamon, A., Tinti, S., Karastathis, V., Fokaefs, A., Camerlenghi, A., Novikova, T., and Papageorgiou, A.: Historical and pre-historical tsunamis in the Mediterranean and its connected seas: Geological signatures, generation mechanisms and coastal impacts, Mar. Geol., 354, 81-109, 2014.

Patacca, E., Scandone, P., Giunta, G., and Liguori, V.: Mesozoic paleotectonic evolution of the Ragusa zone (Southeastern Sicily), Geol. Romana, 18, 331-369, 1979.

Pedley, H. M., House, M. R., and Waugh, B.: The geology of Malta and Gozo, Proc. Geol. Ass., 87, 325-341, 1976.

Pedley, H. M., House, M. R., and Waugh, B.: The geology of the Pelagian Block: the Maltese Islands., in: The ocean basins and margins, Vol. 4B, The Western Mediterranean, edited by: Nairn, A. E. M., Kanes, W. H., and Stehli, F. G., Plenum Press, London, 417-433, 1978

Piacentini, D., Devoto, S., Mantovani, M., Pasuto, A., Prampolini, M., and Soldati, M.: Landslide susceptibility modeling assisted by Persistent Scatterers Interferometry (PSI): an example from the northwestern coast of Malta, Nat. Hazards, 78, 681-697, 2015.

Piatanesi, A. and Tinti, S.: A revision of the 1693 eastern Sicily earthquake and tsunami, J. Geophys. Res-Sol. Ea., 103, 27492758,1998 .
Pignatelli, C., Sansò, P., and Mastronuzzi, G.: Evaluation of tsunami flooding using geomorphologic evidence, Mar. Geol., 260, 6-18, 2009.

Pino, N. A., Piatanesi, A., Valensise, G., and Boschi, E.: The 28 december 1908 Messina straits earthquake (Mw 7.1): A great earthquake throughout a century of seismology, Seismol. Res. Lett., 80, 243-259, 2008.

Postpischl, D.: Catalogo dei terremoti italiani dall'anno 1000 al 1980, CNR, P. F. Geodinamica, Graficoop, Bologna, 239 pp., 1985.

Raji, O., Dezileau, L., Von Grafenstein, U., Niazi, S., Snoussi, M., and Martinez, P.: Extreme sea events during the last millennium in the northeast of Morocco, Nat. Hazards Earth Syst. Sci., 15, 203-211, doi:10.5194/nhess-15-203-2015, 2015.

Said, G. and Schembri, J.: Malta, in: Encyclopedia of the World's Coastal Landforms, edited by: Bird, E. C. F., Springer, Dordrecht, 751-759, 2010.

Sarpkaya, T. and Isaacson, M.: Mechanics of Wave Forces on Offshore Structures, Van Nostrand Reinhold Company Inc., UK, 650 pp., 1981.

Scandone, P., Patacca, E., Radoicic, R., Ryan, W. B. F., Cita, M. B., Rawson, M., Chezar, H., Miller, E., McKenzie, J., and Rossi, S.: Mesozoic and Cenozoic rocks from the Malta Escarpment (Central Mediterranean), AAPG Bull., 65, 1299-1319, 1981.

Scheffers, A. and Scheffers, S.: Documentation of the impact of hurricane Ivan on the coastline of Bonaire (Netherlands Antilles), J. Coastal Res., 22, 1437-1450, 2006.

Scicchitano, G., Monaco, C., and Tortorici, L.: Large boulder deposits by tsunami waves along the Ionian coast of South-eastern Sicily (Italy), Mar. Geol., 238, 75-91, 2007.

Scicchitano, G., Pignatelli, C., Spampinato, C. R., Piscitelli, A., Milella, M., Monaco, C., and Mastronuzzi, G.: Terrestrial Laser Scanner techniques in the assessment of tsunami impact on the Maddalena peninsula (South-eastern Sicily, Italy), Earth Planets Space, 64, 889-903, 2012.

Sunamura, T. and Horikawa, K.: Two dimensional beach transformation due to waves, Proceedings 14th Coastal Engineering Conference, American Society of Civilian Engineers, New York, 920-938, 1974

Tinti, S., Maramai, A., and Graziani, L.: The new catalogue of Italian Tsunamis, Nat. Hazards, 33, 439-465, 2004.

Tinti, S., Armigliato, A., Pagnoni, G., and Zaniboni, F.: Scenarios of giant tsunamis of tectonic origin in the Mediterranean, ISET J. Earthq. Tech., 42, 171-188, 2005.

Vacchi, M., Rovere, A., Zouros, N., and Firpo, M.: Assessing enigmatic boulder deposits in NE Aegean Sea: importance of historical sources as tool to support hydrodynamic equations, Nat. Hazards Earth Syst. Sci., 12, 1109-1118, doi:10.5194/nhess-121109-2012, 2012

Viles, H., Goudie, A. S., Grab, S., and Lalley, J.: The use of the Schmidt Hammer and Equotip for rock hardness assessment in geomorphology and heritage science: a comparative analysis, Earth Surf. Proc. Land., 36, 320-333, 2011.

Vött, A., Bareth, G., Brückner, H., Curdt, C., Fountoulis, I., Grapmayer, R., Hadler, H., Hoffmeister, D., Klasen, N., Lang, F., Masberg, P., May, S. M., Ntageretzis, K., Sakellariou, D., and Willershäuser, T.: Beachrock-type calcarenitic tsunamites along the shores of the eastern Ionian Sea (western Greece) - case stud- 
ies from Akarnania, the Ionian Islands and the Western Peloponnese, Z. Geomorphol., 54, 1-50, 2010.

Williams, D. M. and Hall, A. M.: Cliff-top megaclast deposits of Ireland, a record of extreme waves in the North Atlantic - storms or tsunamis?, Mar. Geol., 206, 101-117, 2004.
Yilmaz, I. and Sendir, H.: Correlation of Schmidt hardness with unconfined compressive strength and Young's modulus in gypsum from Sivas (Turkey), Eng. Geol., 66, 211-219, 2002. 